\title{
Régimen patrimonial del matrimonio
}

Benjamín Aguilar Llanos*

\section{INTRODUCCIÓN}

Por el hecho del matrimonio, hombre y mujer unen sus vidas para realizar un proyecto de vida en común. El matrimonio da lugar a una sociedad conyugal, generadora de deberes y derechos recíprocos entre ambos cónyuges, y de los dos para con la prole que sobreviene. Los deberes y derechos que nacen a propósito del matrimonio son de orden personal y económico, destacando entre los primeros, los deberes de fidelidad, cohabitación y asistencia, y su regulación responde a lograr el fin del matrimonio, esto es, la plena comunidad de vida. Sin embargo, no podemos quedarnos solo en el plano de las relaciones personales y dejar de tratar un tema fundamental, consistente en el soporte económico que garantice la estabilidad y permanencia de la familia, en donde también se dan relaciones de orden económico, pues cada uno de los cónyuges tiene la posibilidad de llevar al matrimonio el patrimonio que tenía cuando era soltero, e incluso la misma sociedad, ya dentro del matrimonio, adquirirá bienes y contraerá obligaciones. Entonces, resulta necesario y conveniente regular estas relaciones con contenido patrimonial, que no solo interesan a los cónyuges, sino también a los terceros que contraten con la sociedad a través de uno de los socios, pues la sociedad conyugal como tal no tiene personería, no existe como sociedad independiente de los que lo integran; a la regulación de las relaciones económicas que se dan en la sociedad conyugal se le denomina régimen patrimonial o régimen económico.

Desde el Código Civil de 1852, pasando por el de 1936, se ha regulado el aspecto patrimonial del matrimonio, sobre la base de la tutela de uno de los

\footnotetext{
Abogado egresado de la Pontificia Universidad Católica del Perú (PUCP), especialista en Derecho de Familia y Derecho de Sucesiones. Es catedrático del Departamento Académico de Derecho de la PUCP.
} 
cónyuges y la sumisión del otro, con la fórmula legal según la cual, el marido debía proteger a la mujer y esta obedecer a su marido. Ambos códigos solo adoptaron el régimen de la sociedad de gananciales como único y obligatorio, aunque parcialmente atenuado por las figuras de la dote y de los bienes reservados, y solo por excepción podía ser sustituido el régimen de gananciales por el de separación de bienes.

Nuestro Código Civil de 1984 no ha regulado el régimen convencional o de las capitulaciones matrimoniales, tal como las entendemos según definición de Diez Picaso y Gullón cuando afirma: «[...] el negocio jurídico por medio del cual se regula el régimen económico conyugal por obra y gracia de la autonomía de los contrayentes [...]». Dichas capitulaciones se constituyen antes de la celebración del matrimonio, y pueden realizarse cambios durante su vigencia, tal como ocurre con la legislación española, que en su artículo 1325 dice: «En capitulaciones matrimoniales, podrán los otorgantes estipular, modificar o sustituir el régimen económico de su matrimonio o cualesquiera otras disposiciones por razón del mismo», cierto es que con la sola limitación de que estas capitulaciones no pueden atentar contra las leyes o las buenas costumbres ni ser limitativas de derechos que correspondan a cada cónyuge, pues de lo contrario tal capitulación será nula.

Ahora bien, nuestro régimen no responde exclusivamente a la voluntad de los contrayentes o cónyuges, sino que está supeditado a la ley, constituyéndose por lo tanto un régimen legal, pues las relaciones económicas de los cónyuges están sujetas a un ordenamiento jurídico determinado; en el caso peruano, la existencia de dos regímenes, el de la sociedad de gananciales y el de separación de patrimonios, pero ambos vienen delimitados por la ley, la voluntad de los contrayentes - y casados - debe sujetarse a lo preestablecido con reglas claras. Sobre el particular, el artículo 300 del Código Civil refiere que cualquiera que sea el régimen en vigor, ambos cónyuges están obligados a contribuir al sostenimiento del hogar según sus respectivas posibilidades y rentas. En ese sentido, se dice que nuestra legislación no ha previsto las capitulaciones matrimoniales, pues en puridad no hay plena autonomía y libertad para que los novios o cónyuges, en su caso, decidan como mejor les parezca fijar las reglas que regularán su vida económica; cierto es, y hay que reconocerlo, se da a los contrayentes, e incluso cónyuges, la posibilidad de escoger entre dos regímenes, el de la sociedad de gananciales o el régimen legal de la separación de patrimonios.

\section{REGIMENES PATRIMONIALES DEL MATRIMONIO}

Existen dos regímenes extremos y contrapuestos entre sí: el de la comunidad universal de bienes y deudas y el de la separación de patrimonios. Además, existen otros regímenes a los que podríamos calificar de mixtos. Analicemos. 


\section{Régimen de la comunidad universal de bienes y deudas}

La sociedad conyugal se convierte en el titular único de un solo patrimonio. No existen patrimonios de los cónyuges, pues el patrimonio del hombre y la mujer antes de casados, y por lo tanto independientes hasta el momento de contraer matrimonio, se fusionan a raíz de este en uno solo, no importando la causa o la época en que los bienes fueron adquiridos o contraídas las deudas.

En este régimen todos los bienes, tanto los llevados al matrimonio como los adquiridos por ambos durante la vigencia del matrimonio, tienen el carácter de comunes, responden por las deudas contraídas tanto por el marido como por la mujer, y los bienes existentes al término del régimen después de cubierto el pasivo, se dividen por igual entre los dos cónyuges.

Este régimen halla su fundamento en la idea de que la comunidad de vida que entraña el matrimonio no puede ser circunscrita a la esfera afectiva o moral, sino que debe abarcar la totalidad de los cónyuges. Se señala que la existencia de patrimonios separados implica intereses independientes y aun eventualmente opuestos, lo que daría lugar a un resquebrajamiento de esta unidad de vida, resultando en cuanto a los intereses económicos, que cada cónyuge fuera un extraño para el otro. Refieren que el matrimonio exige una plena comunidad de vida en todo orden de cosas, en tanto que se está ante un proyecto de vida en común, en donde no debería existir lo tuyo y lo mío pues se trata de dos personas que unen sus vidas para compartir todo, lo bueno y lo malo, y piensan que la existencia de patrimonios separados puede introducir un elemento de desavenencia y por qué no de confrontación.

\section{Régimen de separación de patrimonios}

En lo que se refiere al aspecto económico, el matrimonio no tiene mayores implicancias, pues las relaciones patrimoniales de que son sujeto el marido y la mujer subsisten como se hallaban antes del matrimonio, o se producen después como si este no se hubiera efectuado.

Consiste este régimen en que cada cónyuge hace suyo tanto los bienes que lleva al matrimonio como los que adquiera durante la vigencia de este por cualquier título, así como los frutos de uno u otro, y en ese mismo sentido asume sus propias deudas, y no tiene derecho cuando fenece el régimen matrimonial, a ninguna participación en los bienes del otro cónyuge, sin perjuicio de las normas de sucesión cuando la sociedad ha terminado por muerte de uno de los cónyuges.

El fundamento de esta tesis, curiosamente descansa en el mismo argumento de la comunidad de vida pero con otro enfoque. Así, refieren que la separación de patrimonios es una garantía de concordia entre los cónyuges, al mantener a 
cada uno de ellos apartado de la esfera de los intereses económicos del otro; además, elimina la ambición del pretendiente pobre y despeja la suspicacia del pretendiente afortunado: en otras palabras, impide matrimonios interesados.

Los partidarios de esta tesis señalan que el vínculo matrimonial no debería afectar necesariamente a la actividad económica de los cónyuges, la que puede desarrollarse independientemente, sin perjuicio de las obligaciones por cumplir respecto a las necesidades de los hijos y en general del hogar. Con respecto a terceros no habría mayor problema, pues estos garantizan sus relaciones económicas al celebrar actos jurídicos con el cónyuge titular de su patrimonio, no existiendo confusión pues no existiría para nada la sociedad conyugal como tal, con relevancia económica.

\section{Regímenes mixtos}

Existen diversos regímenes intermedios, algunos de ellos mixtos y otros derivados de los sistemas extremos, a saber: el dotal; el del disfrute por el marido; el de participación en gananciales; el de comunidad de muebles y gananciales; el de comunidad de gananciales; el de comunidad con gestión separada; y el de comunidad con bienes reservados. A continuación, analizaremos los de mayor importancia.

\subsection{Comunidad parcial de muebles y gananciales}

Comunidad de bienes solo respecto de los bienes muebles que los cónyuges llevan al matrimonio o adquieran durante él, los frutos de los bienes propios de cada cónyuge y de los comunes y de los inmuebles obtenidos a título oneroso. En cuanto a los demás bienes, tienen el carácter de propios del marido o la mujer. En este régimen las facultades de administración y disposición corresponden al marido. Se critica este régimen, por las desigualdades que pueden generarse cuando uno de los cónyuges aporta solo o principalmente bienes inmuebles, y el otro única o mayoritariamente bienes muebles, lo que convierte en injusto al régimen.

\subsection{Separación pero con participación de gananciales}

Llamado comunidad diferida o comunidad de administración separada, aquí los bienes adquiridos por los cónyuges durante el matrimonio, quedan sujetos a la administración y disposición de cada uno de ellos como si se tratara de un régimen de separación, pero una vez disuelto el matrimonio, cada cónyuge tiene derecho a participar por mitad, en las ganancias obtenidas por el patrimonio del otro, mediante la doble estimación del patrimonio originario y el 
patrimonio final. En pocas palabras, funciona como la separación de bienes y se liquida como la comunidad de bienes.

\section{RÉGIMEN PATRIMONIAL DEL MATRIMONIO EN EL CÓDIGO CIVIL}

El antecedente del Código Civil de 1984 lo tenemos en el Código Civil de 1936, el mismo que reguló un solo régimen económico en el matrimonio, el de la sociedad de gananciales, sin otra posibilidad de elección. Es cierto que se previó la separación de bienes, pero como consecuencia de un proceso judicial motivado por mala administración de uno de los cónyuges. Recordemos que en la época en que se promulgó el Código de 1936, este respondía al criterio escogido para la organización familiar, y que no era otro que el reconocer al marido como jefe del hogar; de allí la potestad marital. En consecuencia, si el marido tenía las facultades de director y representante legal de la sociedad conyugal, con suficiente capacidad para decidir todo lo concerniente a la economía del hogar, no había necesidad de establecer regímenes económicos, pues bastaba solo uno, el cual era administrado por el jefe de familia, en tanto que la mujer era dependiente de su marido.

La existencia de un solo régimen, y sobre todo las amplias facultades otorgadas al marido respecto del patrimonio social, trajeron muchas injusticias, lo que dio lugar a que en 1968 se expidiera el decreto ley 17838, otorgando a la mujer la facultad de intervenir cuando se tratase de disponer o gravar bienes comunes a título gratuito u oneroso.

La Constitución de 1979, entre las conquistas sociales que trae, encontramos la igualdad del hombre y la mujer ante la ley, lo que lleva a reformular la presencia de la mujer dentro del sistema matrimonial, tanto en lo concerniente al aspecto personal como al económico. Ahora bien, habiéndose dejado la potestad marital del Código Civil de 1936, a la par de la presencia cada vez más activa de la mujer en el campo laboral, se hacía necesario contemplar la posibilidad de que el régimen económico no se agote solo en el de comunidad de bienes, sino también se abra a otras formas que ya eran tratadas en el derecho extranjero. Sin perjuicio de lo señalado, debía contemplarse también que la sociedad conyugal bajo el régimen de sociedad de gananciales, no ofrecería todas las facilidades para un tráfico mercantil adecuado, pues termina siendo poco práctico, en atención a que, para el gravamen o la disposición de los bienes de la sociedad, es indispensable la presencia de ambos cónyuges, sin perjuicio del otorgamiento de poderes; de otro lado, el tercero que adquiere de uno de los cónyuges sin el permiso del otro, no puede invocar a su favor la buena fe, por la presencia de la presunción de que todo lo que se adquiera dentro 
del matrimonio es social, y de ahí, la exigencia de la participación de los dos para los actos de disposición. A todo lo dicho, debe sumarse que cada vez más, y esto es de suma importancia, la presencia de la mujer en todos los campos de la producción lleva a plantear que en ejercicio de su libertad, pueda estimar de su interés que, sin perjuicio de las obligaciones derivadas del matrimonio, requiera tener suficiente autonomía para el manejo de su propio patrimonio.

Pues bien, todo ello ha llevado a considerar que cuando se da el Código Civil de 1984, los legisladores contemplen al lado del régimen de sociedad de gananciales — régimen incorporado al alma del pueblo-, un régimen de separación de patrimonios, con las características propias que el mismo legislador se apura en establecer. En atención a lo señalado, el vigente Código Civil de 1984 contempla la posibilidad de elección entre dos regímenes, el de la sociedad de gananciales y el de la separación de patrimonios, e incluso este último se puede elegir entre los futuros contrayentes antes del matrimonio, para que comience a regir una vez celebrado el mismo. En efecto, dice el artículo 295 del Código, que los futuros cónyuges pueden optar libremente por el régimen de sociedad de gananciales o por el de separación de patrimonios, el cual comenzará a regir al celebrarse el casamiento.

En lo que atañe al régimen de separación de patrimonios que se verá al final de este estudio, podemos adelantar que una rápida mirada a la luz del trabajo notarial, nos conduce a señalar que en lo que va de vigencia el Código es poco usado este régimen, se dice que por desconocimiento de la población. Eso puede ser cierto; sin embargo, creemos que otras consideraciones podrían estar llevando a que no se use la figura como los legisladores lo pensaron. Quizás influya la idiosincrasia del pueblo peruano, que relaciona al matrimonio con una comunidad de vida entre los cónyuges, un compartir todo, pensando que en ello descansa el aprecio, cariño y confianza, y que una eventual separación de patrimonios entrañaría un recelo que puede perjudicar la unión. Por ello, al regular la separación de patrimonios, el legislador peruano lo hace como una figura excepcional dándole un rigor formal extremo.

Esta es la razón por la cual el artículo 295 preceptúa que si los interesados eligen el régimen de separación de patrimonios, deben otorgar escritura pública bajo sanción de nulidad, la cual además para que surta efectos, debe inscribirse en el registro personal, ya que si no se agota con este trámite eminentemente formal, entonces los interesados, aun cuando deseen lo contrario, habrán elegido el régimen de comunidad de gananciales. Si los contrayentes optan por el régimen de gananciales, no es necesario que otorguen escritura pública ni mucho menos que inscriban el régimen en mención en el registro personal.

La separación de patrimonios puede darse, como ya se explicó, antes del matrimonio, y ya dentro de este. Los cónyuges pueden, si es que están bajo el régimen de gananciales, cambiar este por el de separación de patrimonios, 
bastando para ello solo la liquidación del régimen y por cierto cumplir con el trámite formal. Así mismo, pueden cambiar de régimen y pasar de uno de separación por el de gananciales, y pueden variar de régimen las veces que crean necesario, eso sí, siempre y cuando cumplan como ya quedó igualmente mencionado, con los requisitos formales de escritura pública e inscripción registral, como reza el artículo 296 del Código Civil.

Existe otra posibilidad de llegar al régimen de separación de patrimonios impuesto, y ello ocurre como resultado de un proceso judicial por abuso de facultades de administración, o por causar daño en el patrimonio del otro cónyuge. Y una última vía para llegar a la separación de patrimonios y que funciona de oficio, resulta de la declaración de quiebra de uno de los cónyuges, tal como lo manda el artículo 330 del Código Civil.

Analicemos ahora y por separado cada uno de estos regímenes existentes en la ley peruana. Comenzaremos con el de gananciales, estudiando el activo y pasivo, y luego el de la separación de patrimonios.

\section{Régimen de sociedad de gananciales}

Tal como se ha señalado, los códigos civiles republicanos, el de 1852 -que habló de sociedad conyugal_-, el de 1936 y el vigente de 1984 consignan el régimen de sociedad de gananciales, pero hay que precisar que en los dos primeros códigos este era el único régimen regulado, pues si bien es cierto que con el Código Civil de 1936 había la posibilidad de llegar al régimen de separación de bienes entre los cónyuges, esto se daba a través de un proceso judicial por abuso de las facultades de administración del cónyuge que estaba al frente del patrimonio social.

El Código Civil de 1984 utiliza el término sociedad de gananciales, y lo hace más por costumbre o tradición jurídica, ya que en puridad el régimen no da lugar a una sociedad sino a un régimen de corte comunitario, por lo que lo correcto sería denominarlo comunidad de gananciales.

A manera de precisar por qué la sociedad de gananciales no adopta ninguna de las formas societarias conocidas, por cuanto no es sociedad, a continuación y en forma general precisaremos algunas notas características que se dan en la persona jurídica y que no encontramos en la llamada sociedad de gananciales. En efecto, mediante el contrato de sociedad se crea una persona jurídica independiente de los socios. La sociedad de gananciales no tiene personalidad jurídica propia independiente de los cónyuges que la integran. Para ingresar a una sociedad, se requiere de una aportación de cada uno de los socios, lo que no necesariamente sucede en la sociedad de gananciales, en la cual pueden aportar bienes uno solo de los cónyuges. El contrato de sociedad persigue un fin económico, mientras que la sociedad conyugal principalmente tiene por 
objeto solventar la economía del hogar. Las aportaciones que se hacen a una sociedad pasan a ser de propiedad de la misma, por eso, quien las otorga deja de ser propietario, lo que no ocurre con la sociedad de gananciales. Además, la sociedad de gananciales no tiene el elemento característico en la persona jurídica, esto es el ánimo societatis; quizá podría ser una sociedad porque está gobernada por un estatuto, que rige las relaciones personales y patrimoniales de los cónyuges y con terceros, sin embargo, con propiedad nos encontramos no ante una sociedad sino ante una comunidad.

El Código Civil emplea el término sociedad de gananciales y lo refrenda cuando usa los términos de patrimonio social (artículo 313), bienes sociales (artículo 315) y deudas sociales (artículo 317) que podrían llevar a señalar que estamos ante una persona jurídica, pues supuestamente toda idea de patrimonio social, bienes sociales y deudas sociales, puede solo atribuirse a las sociedades con personería jurídica reconocidas en el ordenamiento legal. Sin embargo, ello termina siendo incorrecto tal como ya lo hemos dejado establecido al abordar las características de la persona jurídica, las cuales no se encuentran en la sociedad de gananciales.

Por otro lado, el régimen de comunidad de bienes no debe confundirse con el de copropiedad de bienes. La comunidad de bienes nace por una situación natural que la ley reconoce (matrimonio) y recae sobre un patrimonio donde hay activo y pasivo, patrimonio en el que no puede identificarse titularidades concretas, las mismas que solo se reconocerán cuando se extinga la comunidad. Sin embargo, ello no obsta para que la ley disponga de reglas respecto del manejo del citado patrimonio. En tal mérito y siguiendo este orden de ideas, los cónyuges no tienen establecida una cuota ideal y por ello no es posible disposición de una alícuota inexistente. En lo que se refiere a la copropiedad - titularidad de dos o más personas respecto de un bien- que recae sobre bienes singulares, esta puede devenir en forma obligatoria o voluntaria. El derecho de propiedad de los copropietarios está representado en cuotas ideales llamadas alícuotas, y en cuanto a la facultad de disponer del bien común, es necesario la concurrencia de todos los copropietarios, mas sí es factible las disposiciones de la parte alícuota en cualquier momento por el copropietario. Es de observar las diferencias existentes entre la sociedad de gananciales, o con más propiedad, la comunidad de bienes, y la copropiedad. Sobre el particular, y por resultar de interés para el tema, hacemos mención a la resolución casatoria 1895-98, que nos dice que los bienes sociales son de propiedad de la sociedad de gananciales constituyendo un patrimonio autónomo, distinto del patrimonio de cada cónyuge y por lo tanto no están sujetos a un régimen de copropiedad, es decir los cónyuges no son propietarios de alícuotas respecto a los bienes sociales. 
La sociedad de gananciales en última instancia está dirigida a lograr una perfecta armonía conyugal, lo que va a dar lugar al fortalecimiento de la familia. En atención ello, se prioriza el interés familiar sobre los intereses individuales de sus componentes. Los intereses individuales dan paso al interés familiar, de allí que las normas que regulan el régimen económico, muchas veces terminan limitando o restringiendo las facultades dominales. Verbigracia, cuando los bienes propios de cada uno de los cónyuges rinden frutos, estos no le corresponden en exclusividad al titular del bien propio, sino que son compartidos por ambos cónyuges y con un destino único, solventar la economía del hogar. Así mismo si el titular del bien propio no comparte los frutos de ese bien con su consorte, da lugar a que pueda ser despojado de la administración de su propio bien, la cual se encomienda al cónyuge no titular de ese bien. Obsérvese de estas dos disposiciones que a guisa de ejemplo han sido mencionadas, cómo el interés familiar se superpone al interés individual, en función, en última instancia, de proteger a la familia.

El artículo 301 del Código Civil de 1984, repitiendo la fórmula del Código Civil de 1936, señala que "[...] en el régimen de sociedad de gananciales puede haber bienes propios de cada cónyuge y bienes de la sociedad». En la coexistencia de estos bienes radica la característica de este sistema.

El Código de 1936, para calificar los bienes propios y los bienes comunes, recurrió a una enumeración casuística, con los defectos que ello conlleva, pues pueden quedar al margen algunos y otros devienen en anacrónicos. Ahora bien, con el vigente Código ello no ha variado mucho, pues sigue la enumeración de bienes calificados como propios, y cuando entra a tocar los sociales - antes comunes-, preceptúa que todos los demás son bienes sociales. Analicemos ahora los bienes propios.

\subsection{Bienes propios}

Bienes propios — se dice propio porque pertenece exclusivamente a una personason aquellos que pertenecen en forma exclusiva a cada uno de los cónyuges. En consecuencia, está debidamente identificada la titularidad del citado bien, y por lo tanto, las facultades dominales se ejercen sin mayor contratiempo y sin intervención de terceros. Sin embargo, la existencia de los mismos al lado de lo que se llama la ley bienes sociales, que más adelante se explica, y en tanto que se encuentra dentro del régimen familiar, estos bienes propios, sufren una especie de restricción en cuanto a los frutos, rentas, productos que puedan derivarse del bien, pues ellos ya no le pertenecen en exclusividad al titular del bien sino que vienen a formar parte del llamado patrimonio social, del cual participa también el otro cónyuge. 
Así mismo, y siguiendo la misma línea de razonamiento, la administración del bien propio corresponde a su titular, pero si este no contribuye con los frutos del bien propio a solventar la economía del hogar, dicha administración puede pasar al consorte. En consecuencia, y en aras de proteger a la familia y sin desconocer las facultades dominales, estamos ante la figura del bien propio, pero que en el ámbito del derecho familiar adopta algunas particularidades con respecto a los atributos de la propiedad que, sin embargo, no llegan a afectar al jus disponendi.

El artículo 302 califica como propios de cada cónyuge los siguientes bienes:

a) Los que aporte al iniciarse el régimen de sociedad de gananciales. Aquí el término aporte no tiene el significado que le atribuye el derecho mercantil; como sabemos, cuando se constituye una persona jurídica al que se aportan bienes, estos bienes dejan de pertenecer al aportante para pasar a ser de propiedad de la persona jurídica constituida. En el caso materia de autos, lo de aporte debemos entenderlo como los bienes que figurativamente se lleva al matrimonio, y que por cierto sirven a la sociedad, pero no se pierde la titularidad del bien respecto del que lo llevó. Comprende todos los bienes que cada uno de los cónyuges tenía al momento de iniciarse el régimen, corporales o incorporales, muebles o inmuebles, créditos o rentas, sin atender al origen o título de adquisición. Son estos bienes los que se devuelven a su titular cuando fenece la sociedad de gananciales. Sin embargo, conviene precisar que en el caso de los bienes que constituyen el menaje del hogar - muebles y enseres de una casa-, cuando se produce el término de la sociedad por muerte o declaración de ausencia de uno de los cónyuges, estos bienes son atribuidos según lo dispone el artículo 320, no necesariamente al cónyuge que lo aportó, y que generalmente es el marido, sino al cónyuge sobreviviente o presente. Sobre el menaje, se debe tener en cuenta lo dispuesto por el numeral 321 del Código Civil, al señalar qué bienes están excluidos del menaje ordinario, dentro de los cuales se encuentran, entre los más importantes: el dinero, los títulos valores y otros documentos de carácter patrimonial, las joyas, los vehículos motorizados y en general los objetos que no son de uso doméstico.

b) Los que cada cónyuge adquiera durante la vigencia del régimen de gananciales a título oneroso, cuando la causa de adquisición ha precedido a aquella. Se trata de aquellos bienes sobre los cuales uno de los cónyuges tenía ya un derecho anterior, aportaciones en forma de derechos que se hacen efectivos en fecha posterior. Sobre el particular resulta ilustrativo la casación 1715-96, en donde precisa lo que se entiende por causa de adquisición, y así lo refiere al antecedente necesario o motivo que produce la adquisición del derecho de propiedad, señalando que son supuestos de causa anterior al 
matrimonio, por ejemplo, el acto jurídico sujeto a condición suspensiva que se cumple durante el matrimonio o cuando los bienes vuelven a poder de uno de los cónyuges por acción reivindicatoria o nulidad de contrato. Sin embargo, resulta injusto seguir tratando como bien propio a aquel bien que se adquirió siendo soltero, pero cuya adquisición se hizo bajo la modalidad de pago inicial y saldo por pagar, siendo la inicial insignificante y quedando el saldo mayor a cargo de la sociedad de gananciales. Aquí creemos que debería considerarse una especie de bien mixto: la inicial pagada sería un bien propio y el saldo cancelado a cargo de la sociedad sería un bien social. Claro está que frente a esta tesis se puede argumentar que la calidad de bien propio no impide su uso a favor de la sociedad, y porque la sociedad usufructúa el bien, está llamada a pagar el saldo, sin alterar la calidad del bien. En conclusión, este tema resulta discutible: en el ámbito de la jurisprudencia no existe uniformidad respecto de la solución a seguir en el asunto planteado. Por ejemplo, la casación 838-96 señala que si el bien cuya declaración de bien libre pretende el recurrente fue adquirido con anterioridad a contraer matrimonio, mediante contrato de compra venta a plazos y con pacto de reserva de propiedad - es decir, que el vendedor se reserva el derecho de propiedad hasta que el comprador demandante cumpla con pagar totalmente el precio convenido-, habiéndose cumplido con cancelar dicho precio con posterioridad a la celebración del matrimonio, en vigencia del régimen de gananciales, el bien resulta ser común.

c) Los que adquiera uno de los cónyuges a título gratuito durante la vigencia del régimen, y ello puede ser por causa de herencia, donación o legado. Obsérvese que se trata de liberalidades y que, por lo tanto, el cónyuge beneficiario no se obliga a contraprestación alguna ni mucho menos compromete el patrimonio social para la adquisición del bien; de allí que sin discusión alguna se considere como bien propio. Sin embargo, la renuncia a este tipo de bien por parte de uno de los cónyuges requiere del asentimiento del otro. Esta norma se justifica en razón de que si bien es cierto que el bien ingresa al patrimonio del cónyuge como propio, también lo es que los frutos de ese bien sí son sociales, y por ello se le da participación, tal como lo prevé el artículo 304.

d) Lo que cada cónyuge reciba en concepto de indemnización por accidentes o seguro de vida de daños personales o de enfermedades deducidas las primas pagadas con bienes de la sociedad. Tal como lo señala Cornejo Chávez, se justifica la calidad de bien propio, por cuanto la actividad de los cónyuges no pertenece a la sociedad sino que le pertenece a él. Lo que corresponde a la sociedad son los frutos de esa actividad. Luego, lo que debe tener el carácter de bien social son los rendimientos de la suma recibida como 
indemnización, mas no esta misma que corresponde y reemplaza a la actividad perdida o disminuida.

e) Los derechos de autor e inventor. La ley distingue entre los derechos de autor e inventor y las rentas que de esos derechos puedan derivarse. Son bienes propios debido a la naturaleza absolutamente personal en tanto que la creación de una obra científica, literaria, invención técnica, responde a la persona del creador o inventor, por lo tanto no podría adjudicársele como si fuera un bien producido por la sociedad de gananciales. Las rentas, utilidades que tales derechos pueden originar sí pueden desprenderse de la persona, y en efecto así ocurre a favor de la sociedad conyugal, por ello se consideran bienes sociales. Creemos que debe asimilarse a la calidad de bien propio otros derechos intelectuales, como por ejemplo las marcas.

f) Los vestidos y objetos de uso personal, así como los diplomas, condecoraciones, correspondencia y recuerdos de familia. No cabe duda de la calidad personalísima de estos bienes que están destinados al exclusivo uso de la persona, o que han sido adquiridos en función a los méritos personalísimos, de allí que no podrían considerarse como bienes sociales. Por otro lado, es claro el legislador al señalar que no se consideran menaje los vestidos y objetos de uso personal.

g) Los libros, instrumentos y útiles para el ejercicio de la profesión o trabajo, salvo que sean accesorios de una empresa que no tenga la calidad de bien propio. Se refiere a los elementos indispensables para el ejercicio de una profesión arte, industria u oficio del cónyuge. En tal mérito, deben considerárseles como propios, precisándose que las rentas e ingresos que percibe el cónyuge en el ejercicio de un trabajo son considerados bienes sociales. En cuanto a los accesorios de una empresa a que alude la norma para la calificación de bien propio, esta empresa —individual o unipersonal— también debe tener la calidad de bien propio; caso contrario y siguiendo el principio de que lo accesorio sigue la suerte de lo principal, tales bienes tendrían la calidad de bienes sociales.

h) La renta vitalicia a título gratuito y la convenida a título oneroso cuando la contraprestación constituye bien propio. En cuanto a la renta vitalicia gratuita, se trata de una liberalidad y por lo tanto no ha comprometido el patrimonio social al adquirirse: en esa medida, no cabe duda de que estamos ante un bien propio. Y en lo que atañe al segundo, esto es la renta vitalicia convenida a título oneroso pero cuya contraprestación ha sido realizada con bienes propios, resulta siendo bien propio por la regla de la subrogación, esto es, lo recibido viene a sustituir en su patrimonio a los bienes con que se pagaron las primas realizadas por el cónyuge beneficiario.

i) Las acciones y participaciones de sociedades que se distribuyan gratuitamente entre los socios por revaluación del patrimonio social, cuando estas 
acciones o participaciones sean bien propio. Se trata de una actualización del valor de bienes anteriores por problemas de devaluación o inflación. Obsérvese que no se trata de un aumento real de ese patrimonio, sino simplemente de una actualización del valor. Ahora bien, si esas acciones que representan el patrimonio social de la sociedad pertenecen al cónyuge en calidad de bien propio y con la autorización pertinente se actualiza el valor del referido patrimonio social, lógico es que ahora ese patrimonio esté representado por un número mayor de acciones (incremento del capital social), y que tales acciones se distribuyan en forma gratuita entre los socios, dentro de los cuales está el socio cónyuge, quien recibe un número determinado de acciones o participaciones, según fuera el caso, en consecuencia estas tienen que seguir la suerte de las acciones originarias, y si estas eran propias, las segundas también tendrán que ser propias.

\subsubsection{Facultades que la ley concede a cada cónyuge sobre sus bienes propios}

Ha quedado establecido que el bien propio responde al dominio exclusivo de uno de los cónyuges respecto de un bien en particular. Así mismo, se ha señalado que tratándose de intereses patrimoniales, estos quedan subordinados al interés familiar, y por ello la propiedad del bien termina siendo restringida o limitada en algunos casos. Pues bien, bajo estas premisas diremos que si bien es cierto, la propiedad confiere a su titular las facultades de uso, disfrute, disposición y reivindicación, el cónyuge propietario del bien tiene en general estos atributos, pero con ciertas particularidades que pasamos a analizar.

\section{a) Administración}

Significa gestión, gobierno de intereses o bienes. Por lo tanto, el cuidado del bien, su gestión y gobierno corresponderán en principio al titular del respectivo bien. Decimos en principio pues en el derecho de familia, y en vista del interés familiar que debe primar sobre el interés individual de cada uno de los cónyuges, el Código en ciertos casos termina restringiendo esta administración. Veamos.

La regla es que cada cónyuge administra libremente sus bienes propios. No obstante, esta facultad admite tres excepciones:

1. El cónyuge titular del bien propio resulta propietario del mismo. Sin embargo, los frutos, rentas que generen esos bienes propios ya no le corresponden en exclusividad, sino que se constituyen en bienes sociales. Ahora bien, puede darse el caso de que el titular del bien propio no contribuya con dichos frutos o productos al sostenimiento del hogar, que es a donde están destinados los bienes sociales. En ese caso, el otro cónyuge puede 
pedir al juez que pasen a su administración en todo o parte esos bienes. Claro está que a fin de evitar abusos se exige la constitución de garantía. En consecuencia, el titular del bien propio no resultaría administrando su bien. Obsérvese en la regla consignada en el artículo 305 del Código Civil, una especie de sanción al cónyuge titular del bien, a quien no se despoja de la titularidad pero sí de la administración, pues está perjudicando económicamente a su consorte, en tanto que al considerarse los frutos de ese bien como sociales, ambos cónyuges tienen derechos sobre tales frutos, pero también se va en contra del interés familiar, puesto que esos frutos deben dirigirse a atender las necesidades del hogar. El pedido para que pase la administración al cónyuge no titular del bien se sigue en proceso sumarísimo.

2. El segundo caso en que excepcionalmente los bienes propios de uno de los cónyuges son administrados por el otro es cuando él mismo lo permite, y ello es viable pese a que, como sabemos, no es posible contratar entre cónyuges respecto de los bienes de la sociedad. Sin embargo, esta norma tiene una excepción tal como en forma expresa se consigna en el artículo 146 del Código Civil, que permite la representación entre cónyuges. En esta circunstancia, el cónyuge no tiene más facultades que la de la mera administración y está obligado a devolver los bienes a su propietario cuando este lo requiera.

3. La tercera excepción se produce por situaciones de hecho que impiden al titular del bien propio estar al frente de su bien, y estos son los casos de interdicción, desaparición. En esta situación no solo se afronta la eventualidad de que el propietario no se encuentre al frente de su bien, con el perjuicio que puede ocasionar ello, sino que el deber del consorte, dentro de los deberes de asistencia que impone el matrimonio, lo lleva a cuidar ese bien. Recordemos sobre el particular que tratándose de una interdicción que da lugar a la designación de un curador, tal cargo recae en el cónyuge, y en el supuesto de la desaparición, da lugar a una curaduría de bienes, que igualmente corresponde ejercerla al consorte. Esta excepción se encuentra regulada en el artículo 314 del Código Civil.

b) Gravamen y disposición

Refiere el Código Civil que, respecto de su bien propio, cada cónyuge puede disponer de él o gravarlo. Por lo tanto, el cónyuge propietario no necesita autorización de nadie para gravar o disponer de su bien propio, lo que parece pertinente y lógico atendiendo a las facultades que concede la propiedad a su titular. Sin embargo, no olvidemos el interés familiar que hay detrás de toda esta regulación de los intereses económicos del matrimonio. Pese a ello, nuestros legisladores no han puesto condicionamientos ni muchos menos se ha 
restringido o limitado la facultad de disposición. Esto puede dar lugar a abusos, sobre todo en casos referidos al inmueble donde reside la familia y cuya titularidad corresponde a uno de los cónyuges. En esa situación, salido el inmueble del patrimonio del cónyuge, la familia podría quedar desamparada. Sobre el particular, la legislación argentina —a través de la ley 17711, específicamente el artículo 1277- exige el consentimiento de ambos cónyuges para disponer o gravar el inmueble propio de uno de ellos, donde radique el hogar conyugal aun después de disuelta la sociedad conyugal. Trátese en este caso de un bien propio o ganancial, y la exigencia con respecto al hogar conyugal subsiste mientras haya hijos menores o incapaces. Como es de verse, se trata de una evidente prohibición legal que obedece a un reclamo de jerarquía superior a los intereses individuales. Particularmente, comulgamos con esta prohibición para proteger los intereses de la familia.

\subsection{Bienes sociales}

En el Código Civil de 1936, a los bienes sociales se les denominó bienes comunes. Decir bienes sociales no significa referirnos a la sociedad de gananciales como una forma societaria, pues tal como dijimos, la sociedad de gananciales más que una persona jurídica bajo la forma de sociedad es una comunidad de bienes: su denominación persigue diferenciarlos de los llamados bienes propios que tienen sus propias reglas. Además, resulta atendible que el legislador no pueda haber previsto todos los bienes que tienen la calidad de bienes propios, y por lo tanto haya incurrido en omisiones. En esa circunstancia, siempre bajo la óptica del interés familiar y como una especie de categoría residual, se señala que cualquier bien que no esté expresamente considerado como propio tiene la categoría de bien social. Así lo encontramos en el artículo 310 del Código Civil de 1984, que señala son sociales todos los bienes no comprendidos en la enumeración del artículo 302 —artículo referido a los bienes propios-. Sin embargo, por la importancia del caso se precisa algunos bienes sociales específicos:

a) Los que cualquiera de los cónyuges adquiera por su trabajo, industria o profesión. Los ingresos que obtiene el cónyuge trabajador bajo cualquier denominación, sueldo, salario, remuneraciones, honorarios, haberes, se consideran sociales, o en palabras sencillas. no solo corresponden al cónyuge trabajador sino igualmente al otro cónyuge, pues ambos son consortes («socios») de la comunidad de bienes. Este bien social es el más importante de todos, no solo por su frecuencia y periodicidad, sino porque constituye el ingreso directo con el cual se solventan las necesidades del hogar. Nos parece sumamente importante este bien social tal como ha sido regulado, sobre 
todo en una sociedad como la peruana en la que el machismo, aún predominante, lleva a creer a algunos maridos que se dedican a una actividad productiva, mientras que su consorte cuida el hogar e hijos, que por ser ellos los que generan tal riqueza, debe pertenecerles en exclusividad tales ingresos. Esto resulta no solo ilegal sino injusto y discriminatorio. Tal como la jurisprudencia lo ha entendido, creemos que entran igualmente en la calidad de bien social, la renta de las pensiones de jubilación, cesantía, retiro, percibidos durante el matrimonio.

b) Los frutos y productos de todos los bienes propios son sociales, y con mayor razón, los frutos y productos de los bienes sociales. No ofrece duda alguna la calidad de bien social respecto de los frutos y productos del bien social. Sin embargo, algunos han objetado o reparado el hecho de que los frutos y productos de los bienes propios tengan la calidad de social. Lo hacen en función de las facultades que otorga el dominio sobre una cosa, usando la lógica elemental de que si uno es propietario de un bien, y si ese bien genera frutos, tales frutos deben corresponderle al titular del bien. Sin embargo, en sede familiar, tal como dijimos, el interés particular no debe estar por encima del interés familiar. Por ello, y porque tales frutos del bien al ser considerados sociales se dirigen a atender las necesidades del hogar, una calificación como la que ha dado el legislador nos parece correcta. Además, tratando de ser justo, es una de las formas de proteger mejor al cónyuge que no tiene bienes propios.

c) Las rentas de los derechos de autor e inventor. $\mathrm{Al}$ analizar los bienes propios, aludimos a los derechos de autor e inventor por su calidad de personalísimos. Ahora bien, en el supuesto bajo comentario, la referencia es a las rentas que produzcan tales derechos, pues estas son en realidad frutos, y por lo tanto reciben el mismo tratamiento que los frutos del bien propio.

d) Los edificios construidos a costa del caudal social en suelo propio de uno de los cónyuges, abonándose a este el valor del suelo al momento del reembolso. Es de observar que en este caso aparentemente estaríamos ante un bien mixto, propio en cuanto al predio, y social en lo referente a la fábrica levantada sobre el predio. Sin embargo, por seguridad jurídica y para no crear incertidumbre de estar ante parte de un bien que sea propio y parte que no lo sea, existe la presente regla de considerar social a estos edificios —entiéndase fábricas edificadas sobre el suelo-. No obstante, y para no ser injusto, deberá reintegrarse al cónyuge el valor del bien propio cuya pérdida sufre por razón de este cambio de calidad.

Ha dejado de regular el legislador del Código Civil de 1984 las ganancias obtenidas por el marido o la mujer en las loterías, y que ahora podríamos extender a todos los juegos de azar. Sobre el particular, el Código Civil de 
1936 contempló estos bienes como comunes, norma con la cual concordamos. En el presente, si alguno de los cónyuges obtiene un premio bajo la modalidad comentada, creemos que debería igualmente considerarse como social, para así beneficiar a la familia y no quedarse en el plano reservado y egoísta de beneficiar exclusivamente al cónyuge que lo obtuvo. En todo caso, al no haber sido regulado quedará a criterio del juez el resolver cada caso concreto, siempre dentro del criterio del interés familiar. Sobre el tema de las loterías, es interesante la legislación española, cuando en su artículo 1351 senala que las ganancias obtenidas por el marido o la mujer en el juego, o las procedentes de otras causas que eximan de la restitución, pertenecerán a la sociedad de gananciales.

Un tema afín con los bienes sociales, es la prohibición de celebrar contratos entre los cónyuges respecto de los bienes de la sociedad, tal como lo manda el artículo 312, excepto cuando se trata de poderes. La idea es proteger a terceros con posibles colusiones entre los cónyuges. Ahora bien, esta razón también la encontramos en el caso de la separación de patrimonios y, sin embargo, no existe norma prohibitiva en ese régimen.

\subsubsection{Facultades que la ley otorga a los cónyuges sobre los bienes sociales}

Con la legislación anterior, bajo el régimen de la potestad marital era el marido el que administraba los bienes sociales y quien tenía la facultad de disposición. Solo le era prohibido disponer de los bienes sociales a titulo gratuito, norma que llevó a muchas injusticias, y que tal como ya ha sido mencionado, dio lugar a que en 1968 se dictara el decreto ley 17838, que modificó el artículo 188 del Código de 1936, exigiendo la presencia de la cónyuge en los actos de disposición de los bienes comunes. Hoy, con la igualdad legal del hombre y la mujer ya no existe la potestad marital, y la mujer y el marido tienen iguales derechos y responsabilidades en el hogar, lo que significa que en el ámbito económico sean los dos, con iguales derechos y deberes, los que se encuentren al frente del patrimonio social. Veamos.

\section{a) Administración}

En atención a todo lo ya señalado respecto de la igualdad de derechos y deberes de ambos cónyuges en el hogar, la administración de los bienes sociales compete a los dos, pero permite que cualquiera de ellos faculte al otro, para que asuma con exclusividad dicha administración respecto de todos o alguno de los bienes. Recuérdese sobre el particular, la norma contenida en el artículo 146 del Código Civil que permite la representación entre cónyuges. El común derecho de administración de los bienes sociales tiene una excepción, cuando 
uno de los cónyuges está impedido por causa de interdicción u otro motivo, o cuando se ignora su paradero, se encuentra en un lugar remoto o ha abandonado el hogar. En todos estos supuestos, el otro cónyuge administra los bienes sociales de los que depende el sostenimiento del hogar. Esta norma es razonable atendiendo a la urgencia del cuidado del patrimonio social, y además porque en el caso de la interdicción del cónyuge o la desaparición del mismo, el deber de asistencia cobra importancia en el campo económico, pues el cuidado de esos bienes no solo lo hace para sí el cónyuge que pasa a administrar, sino también para el cónyuge en desgracia. En cuanto al abandono del domicilio conyugal, la situación es diferente, al igual que el trato legal, pues en ese supuesto, si bien es cierto que el cónyuge que permanece en el hogar conyugal tiene el deber de cuidar los bienes, también lo es que el inicio de la separación de hecho da lugar a la finalización de la sociedad de gananciales, tal como se verá más adelante.

\section{b) Gravamen y disposición}

Aunque el numeral 315 del Código Civil exige la intervención de ambos cónyuges, se regula por separado la adquisición tratándose de bienes muebles o inmuebles. Veamos. Según este dispositivo legal, en la adquisición de bienes muebles no es necesaria la participación de ambos cónyuges, entendiéndose que sí lo es para la adquisición de los bienes inmuebles. Sobre el particular surge la interrogante de por qué el trato diferente: quizás los legisladores piensan que los bienes muebles siempre son de escaso valor. Ahora bien, la excepción prevista en la norma respecto a la adquisición de bienes muebles merece dos observaciones: en primer lugar, desvirtuar el concepto de que el bien mueble siempre es de menor valor que el inmueble, verbigracia un paquete de acciones de una empresa u compañía de gran significación económica; en segundo lugar, la compra de un bien supone el pago del precio de ese bien, lo que implica a su vez un acto de disposición. Estas observaciones nos llevan a sugerir la modificación de la norma, para que ambos cónyuges intervengan también en los actos de adquisición de los bienes muebles. La excepción debería limitarse única y exclusivamente a determinadas adquisiciones necesarias en función de los requerimientos domésticos de la familia; de esa manera, se guardaría coherencia con el segundo párrafo del artículo 292, sobre la representación legal de la sociedad conyugal para necesidades ordinarias del hogar conyugal, en la que la representación recae indistintamente en cualquiera de los cónyuges.

La norma comentada contiene un mandato, una orden, y por ello resulta imperativa. En consecuencia, si un cónyuge dispone de un bien social sin la intervención de su consorte, tal disposición resulta nula. Sobre el particular resulta ilustrativa la resolución casatoria 513-96, la misma que señala el carácter 
obligatorio del artículo 315 del Código Civil, porque impide que cualquiera de los cónyuges pueda disponer de los bienes sociales sin la intervención o un poder especial del otro. La violación de la norma sobre la disposición conjunta ha creado interpretaciones varias: unos señalan que se trata de un acto nulo, mientras que otros se pronuncian por la anulabilidad del acto, tal como lo hace el proyecto de reforma del libro de familia del Ministerio de Justicia, que propone que la sanción debe ser demandada por el cónyuge que no intervino o sus herederos. Sobre este asunto, y en vista del interés familiar existente - que debe ser protegido en función de todos los integrantes del núcleo familiar-, creemos que una nulidad es la que debe proceder en caso de contravención a la disposición conjunta de los bienes sociales, porque la disposición es un acto que va en contra de una norma imperativa.

En cuanto a las leyes especiales a que alude la norma, y en las que tampoco es obligatorio la concurrencia de ambos cónyuges para los actos de disposición sobre bienes muebles, a guisa de ejemplo mencionamos algunas, como la ley 27287 en su sexta disposición final, que indica que: «[... en la transferencia o constitución de gravámenes, sobre los títulos valores emitidos y transferidos a favor de una persona natural, no se requiere la intervención del otro cónyuge, la misma regla rige para los valores representados mediante anotación en cuenta»; la ley 26361, artículo cuarto, que dice que: «[...] se presume sin admitir prueba en contrario que los bienes materia de negociación en bolsa tienen el consentimiento de ambos cónyuges»; la Ley de Mercados de Valores en su artículo 113 que indica: «[...] que en las transacciones que se efectúen en los mecanismos centralizados regulados por esta ley, se presume de pleno derecho el consentimiento del cónyuge del enajenante»; y la Ley de Bancos que en su artículo 227 dice que: «[...] en el establecimiento de cuentas corrientes por personas naturales y en las operaciones que se efectúen con las mismas, se presume de pleno derecho el consentimiento del cónyuge titular de la cuenta».

\subsection{Deudas personales y sociales}

Ha quedado claro a la luz de la legislación, la calidad de patrimonio autónomo de la sociedad de gananciales. Pues bien, este patrimonio no se forma solo con bienes que constituyen el activo sino también con las deudas que integran el pasivo, las cuales pueden ser propias de cada cónyuge o sociales.

Decir deudas sociales no es referirse a la sociedad conyugal como deudora, porque la sociedad de gananciales nunca puede obligarse directamente; por cuanto carece de personalidad jurídica, los que actúan y se obligan son siempre el marido y la mujer. Sin embargo, el fundamento de las deudas personales se halla en la finalidad perseguida por el cónyuge al contraerlas, y así, si no han servido para atender las cargas del hogar, se consideran personales. 


\subsubsection{Deudas personales}

Al calificar los bienes propios señalamos, en primer lugar, que tales bienes lo constituían los adquiridos antes del nacimiento del régimen de la sociedad de gananciales. Pues bien, este criterio también sirve para considerar a una deuda como propia y personal del cónyuge que la contrajo antes del matrimonio. En general, los bienes propios de cada cónyuge responden por sus deudas personales, y así las deudas que este contrajo antes de la vigencia del régimen de gananciales, no tienen por qué afectar los bienes propios del otro, ni tampoco los bienes sociales. Sin embargo, si las deudas se hubieran contraído en beneficio del futuro hogar, por ejemplo, el contrayente que asume una deuda con un banco para amoblar su futura casa conyugal, y luego de casado comienza a devengarse la obligación del pago del préstamo y no tuviere bienes propios, entonces los bienes sociales quedan afectos. Ello nos parece razonable, por cuanto dichos bienes están destinados al servicio del hogar conyugal, y práctico si se tiene en cuenta que dentro del matrimonio, principalmente lo que existe como bienes son los ingresos que perciben los cónyuges por su trabajo, y dichos bienes, como sabemos, tienen la calidad de sociales. En atención a ello mostramos conformidad con lo dispuesto en el artículo 307 del Código Civil.

Otro supuesto está referido a la deuda a título personal contraída por uno de los cónyuges estando vigente el régimen de sociedad de gananciales, deuda personal y que por lo tanto debe ser honrada con sus bienes propios, no teniendo por qué afectar los bienes propios del otro. Hasta aquí resulta lógica la norma, pero si se ha probado que esa deuda personal se contrajo en provecho de la familia, y el deudor carece de bienes propios, entonces dice el artículo 308 del Código Civil, que los bienes propios del otro consorte terminan siendo afectados en el pago de tales deudas. Sobre el particular cabe preguntarse porqué el legislador no se pronunció primero por la afectación de los bienes sociales; si fueran insuficientes o no los hubiera, recién se podría afectar los propios del otro consorte, tal como sucede en el supuesto del numeral 307, supuesto basado en la consideración de que la deuda fue contraída en provecho de la familia. Por ejemplo, uno de los cónyuges adquiere personalmente un préstamo para sufragar los gastos de una intervención quirúrgica de uno de los hijos del matrimonio, y al devengarse tal obligación, resulta que carece de bienes propios. En ese caso, ¿por qué no afectar en primer lugar los bienes sociales y si no los hubiera o si son insuficientes recién pensar en afectar los propios? Nos parece que el legislador ha dado tratos diferentes a situaciones similares.

Resulta claro el criterio para distinguir entre deudas personales y deudas sociales. Así, si la deuda se contrajo para destinarla en beneficio de la familia, 
será considerada una deuda social. En caso contrario, será considerada un deuda personal y tendrá que ser pagada con bienes propios del deudor, regla esta a la que debe sumarse los dos supuestos anteriores ya estudiados: la deuda que se contrajo antes del matrimonio, pero para atender asuntos del futuro hogar, y que de no haber bienes propios, termina afectando a los bienes sociales; y la deuda contraída dentro de la sociedad de gananciales, para atender asuntos de interés familiar, y que de no haber bienes propios, termina afectando los bienes propios del otro consorte. Sin embargo, hay casos en que los bienes propios del cónyuge pueden responder por deudas que no son suyas sino de la sociedad, como aquel en que los bienes sociales no bastan para cancelar las deudas que son de cargo de la sociedad, supuesto en el cual responden los bienes propios de cada cónyuge a prorrata, es decir, en proporción a sus respectivos montos. Un ejemplo de este supuesto contemplado en el numeral 317 , sería el caso de una sociedad conyugal en la que los dos cónyuges gestionan juntos un préstamo para atender una urgencia familiar de uno de los hijos comunes, y luego de devengada esa deuda, la misma que debería afectar los bienes sociales, no existen tales bienes o son insuficientes. En tal caso, terminan afectándose los bienes propios a prorrata. Ahora bien, en justicia debería existir un reembolso a favor del cónyuge aportante, en el caso en que la deuda internamente social hubiera sido saldada con fondos propios de uno solo de los cónyuges. El que empleó sus fondos debería ser compensado, lo que podría hacerse en el proceso de liquidación de la sociedad.

Con respecto de la deuda que deriva de la responsabilidad extra contractual de uno de los cónyuges, no solo quedan libres de afectación los bienes propios del otro cónyuge, sino también la parte que le correspondería en los bienes de la sociedad en caso de liquidación, esto es en tesis general, el 50\% de los bienes sociales, tesis recogida en el artículo 309 del Código Civil y que nos parece correcta, en virtud de que se trata de deudas personalísimas y que en nada han beneficiado a la sociedad. Sobre el particular resultan ilustrativas las resoluciones casatorias 50-96 y 1895-98. La primera refiere que los bienes propios de uno de los cónyuges no responden por las deudas personales del otro. Siendo así, la responsabilidad extracontractual de uno de los cónyuges, como acto absolutamente personal, no tiene por qué afectar el patrimonio del otro ni perjudicarlo eventualmente en la parte que le correspondería por concepto de gananciales. La segunda alude a la obligación de pagar el monto de una reparación civil impuesta a uno de los cónyuges en virtud de una sentencia penal, refiriendo que constituye una obligación personal por la que no pueden responder los bienes sociales de la sociedad de gananciales. 


\subsection{2. ¿Pueden afectar las deudas personales el patrimonio social?}

Debemos señalar que algunos autores calificados, como Tedeshi, Castán Tobeñas Colín y Capitant Guastavino, niegan cualquier derecho que sobre los bienes sociales puedan pretender los acreedores personales.

Nuestro Código Civil, en los artículos 307 y 308 ya analizados, no hace referencia a la posibilidad de que los acreedores personales puedan dirigirse, en vigencia de la sociedad de gananciales, por deudas contraídas individualmente en su propio beneficio, contra el patrimonio social o contra la porción indivisa que sobre los mismos le correspondería a su deudor.

Por nuestra parte, y en consideración a haber calificado la sociedad de gananciales más que como una sociedad, como una comunidad de bienes a la que no debe aplicársele las normas de la copropiedad en función de la diferencia que existe entre ellas, consideramos al igual que estos conocidos juristas que no cabe que por deudas personales se pueda afectar el patrimonio social, ni la expectativa de derecho ganancial del cónyuge deudor con medidas cautelares $\mathrm{u}$ otras, lo que no significa desconocer el derecho del acreedor a verificar su crédito. Sin embargo, no ha de hacerlo por esa vía; el mismo legislador contempla la posibilidad de la declaración de insolvencia del cónyuge deudor, y ante esa declaración, finalizar el régimen de la sociedad de gananciales, y por ende, liquidarla, momento en el cual —al ya estar debidamente identificadas las cuotas de los cónyuges - se podrá proceder al embargo y remate de los bienes que le pudieran corresponder al cónyuge, o si no ha habido aún partición, al embargo de la alícuota y su posterior ejecución.

En consecuencia, creemos que el acreedor no podrá:

- Solicitar la partición de la sociedad de gananciales, porque dicha partición solo se efectúa cuando fenece la sociedad, existiendo causales precisas que dan lugar al término de esta sociedad. En ese mismo orden de ideas tampoco podrá, como es obvio, ejecutar la futura porción que le correspondería a su deudor, por cuanto la adjudicación se produce luego del fenecimiento de la sociedad y su posterior adjudicación de bienes.

- No podrá pedir la venta forzada de la parte indivisa de su deudor antes de la partición, por cuanto la cuota resulta indeterminable sin una previa liquidación, además de que tal cuota abstracta es indisponible durante la vigencia de la sociedad. Por otro lado, si fuera posible la venta forzada de la parte indivisa del cónyuge deudor sobre el bien social, originaría una copropiedad entre el tercero adquirente y el otro cónyuge, con todos los problemas que ello acarrearía.

Sin embargo, no poder dirigirse contra la cuota del deudor sobre el patrimonio social, trae como consecuencia la postergación indefinida que sufrirían 
los derechos de los acreedores, y la disminución de la garantía que ofrecerían las personas casadas bajo el régimen de gananciales. Por ello, existen opiniones diferentes, incluso a nivel de la magistratura, en el sentido de que sí sería procedente, no la venta forzada de los bienes de la sociedad, mas sí tomar las medidas preventivas en resguardo de su derecho, como anotación de embargo.

Sobre el particular, resulta interesante la resolución casatoria 1718-99 que señala que la Corte Suprema establece que es procedente el embargo de los derechos y acciones que tiene el cónyuge deudor sobre sus bienes sociales; así mismo dice que la sociedad conyugal ha sido considerada como patrimonio autónomo por el artículo 65 del código adjetivo para efectos de su representación en juicio, lo que no determina que sus bienes sean inembargables; que los derechos que el deudor casado tenga en los bienes sociales con su cónyuge también forman parte de su patrimonio, y que no hay norma legal que impidan que sean embargados en garantía de una obligación. Por eso dice que el artículo 330 del código sustantivo establece que la declaración de insolvencia de uno de los cónyuges determina de pleno derecho la sustitución del régimen patrimonial. Sin embargo, se dice que no debe confundirse la medida cautelar de embargo con la ejecución de un bien social de la sociedad conyugal, que no procederá hasta que se produzca la separación de patrimonios. Es clara la posición de los magistrados en la presente resolución. No obstante, creo que existe confusión al fundar la posibilidad de embargo de un bien social por una deuda personal en lo dispuesto en el artículo 330 del Código Civil. Como resulta obvio, para que funcione el cambio de régimen (fenecimiento de la sociedad de gananciales), primero hay que agotar la declaración de insolvencia; verificado esto, estaremos ante un nuevo régimen, el de la separación de patrimonios — previo inventario y liquidación de la sociedad—, y solo recién se podrá embargar la alícuota que le corresponde al cónyuge deudor. Esto no puede funcionar al revés, pues al no existir declaración de insolvencia y liquidación de sociedad, no hay aún identificación de cuotas.

A diferencia de los criterios que manejan los magistrados en la resolución casatoria comentada, existe otra, la 1895-98, que refiere que los bienes sociales son de propiedad de la sociedad de gananciales, constituyendo un patrimonio autónomo distinto del patrimonio de cada cónyuge. Por lo tanto, esos bienes no están sujetos a un régimen de copropiedad, es decir, los cónyuges no son propietarios de alícuotas respecto a los bienes sociales. Por ello es que cuando se ejercita un acto de administración o de disposición de un bien social, quien lo ejercita es la sociedad de gananciales. Igualmente, cuando acontece la liquidación de la sociedad de gananciales, quien transfiere los gananciales a cada cónyuge es dicha sociedad, y no se trata de una mutua transferencia de derechos entre cónyuges. Existiendo criterios diferentes, la posibilidad de resoluciones contradictorias es evidente. Por eso se hace urgente una precisión legal 
acerca de este tema, sobre el cual hemos fijado nuestra posición que podría resumirse de la siguiente manera: la esencia de la sociedad de gananciales, o más propiamente, de la comunidad de bienes, no son los activos ni los pasivos sino en buena cuenta ser una sociedad de resultados, que solo se conocen cuando fenece, a diferencia de una sociedad comercial cuyo objetivo es el lucro y cuyos resultados pueden averiguarse periódicamente. Por lo tanto, estando vigente la sociedad de gananciales, resultan indeterminables las cuotas de los llamados socios o, con mayor propiedad, consortes, y por ende inembargables tales cuotas hasta que se produzca su fenecimiento.

\subsubsection{Deudas de la sociedad}

Hemos señalado que la sociedad no es una persona jurídica en cuyo nombre puedan suscribirse obligaciones. Las deudas solo afectan a los bienes sociales por intermedio de uno o ambos cónyuges que se obligan personalmente, pero en beneficio de la sociedad.

Se consideran deudas de la sociedad a todas aquellas que tienen por objeto levantar las cargas que puntualiza el artículo 316, o aquellas que sin estar dirigidas a ese fin, han sido contraídas legalmente por los cónyuges dentro de su común facultad de disposición de los bienes de la sociedad. Se llama carga al tributo o gravamen que se impone a una persona o cosa. En el supuesto bajo comentario, debemos entenderlo como obligaciones de la sociedad de gananciales y como tales deben ser honradas, obligaciones sociales tipificadas en consideración al fin perseguido al momento de contraerlas, y que no es otro que el beneficio de la familia.

Son de cargo de la sociedad, según el artículo 316 del Código Civil, los siguientes:

1. El sostenimiento de la familia y la educación de los hijos comunes. Sostenimiento y educación debemos entenderlos dentro del concepto jurídico de alimentos, dentro del cual también deben ser considerados los rubros de habitación y asistencia médica, y tratándose de menores, los gastos referidos a la recreación. Ahora bien, son claramente conocidas las obligaciones emergentes del matrimonio, esto es, el deber alimentario de los cónyuges entre si y para con sus hijos. En consecuencia, corresponde a ambos cubrir estas necesidades de los miembros de la familia, y por lo tanto, no hay duda alguna que dichos gastos, urgentes, necesarios y prioritarios, deben ser cubiertos con los bienes de la sociedad pues se dirigen a atender una necesidad de la sociedad. Por otro lado, lo normal y corriente es que estas obligaciones sean cubiertas con los ingresos de los consortes obtenidos como producto de su trabajo, bienes que como sabemos tienen las calidad de sociales. 
2. Los alimentos que uno de los cónyuges está obligado por ley a dar a otra persona. Este supuesto se ubica ya no dentro del entorno familiar matrimonial, sino que alude a una obligación alimentaria de uno de los cónyuges con terceras personas, como por ejemplo la deuda por alimentos que pueda tener el cónyuge con un hijo extramatrimonial. Llama la atención que esta deuda termine afectando el patrimonio social, pues si como sabemos la deuda se deriva de un hecho propio del cónyuge, entonces debería ser tratada como deuda personal. Sin embargo, se trata de cubrir un estado de necesidad de una persona y que debe ser cubierto con urgencia, por ser vital. En tal medida, consideramos que haciendo una excepción, el legislador trata esta deuda como social, lo que implica que si el cónyuge deudor de los alimentos no puede cumplir con su obligación por carecer de ingresos, cabe una medida cautelar contra los ingresos del otro consorte, pues sabido es que tales ingresos derivados del trabajo son sociales, y como tal, deben soportar las cargas sociales. La norma puede parecer injusta, pero no olvidemos que se trata del derecho alimentario: por sus características, su atención resulta prioritaria; la disposición legal cubre todos los casos en que el cónyuge resulte deudor alimentario.

3. El importe de lo donado o prometido a los hijos comunes por ambos cónyuges. La norma distingue dos momentos. En primer lugar, lo ya realizado, en este caso, la donación efectuada por ambos cónyuges al hijo común. En esa circunstancia termina afectando el patrimonio social, pues si solo lo realiza uno de los cónyuges debe entenderse que lo hace con sus bienes propios, y si no los tuviera no será posible hacer esa liberalidad, porque como dijimos no es posible disponer de alícuotas no identificables. En segundo lugar, la norma alude a lo prometido u ofrecido por ambos cónyuges. En este caso, hay una obligación común y que por lo tanto debe considerase como un obligación social, la misma que al materializarse afecta el patrimonio social; en cuanto que este ofrecimiento o promesa pueda realizarse para ser cumplida con bienes propios, no hay problema alguno, y si la promesa se hace para ser cumplida con gananciales, también será posible y terminará afectando el patrimonio social. Bajo estos conceptos tenemos que contemplar los anticipos de herencia regulados en el derecho sucesorio, y teniendo siempre presente la distinción nítida que hace nuestro legislador entre cuota hereditaria y gananciales, tal como se ve en lo normado en el artículo 730 del Código Civil.

4. Las reparaciones y mejoras necesarias, las útiles y de recreo, hechas en bienes propios con el consentimiento del titular, y las realizadas en los bienes sociales, así como los tributos y retribuciones que los afecten. Reparación alude al arreglo de un daño sobre la cosa, a la compostura de la misma, mientras que mejoras se refiere a lo gastado en el bien para conservarlo, 
perfeccionarlo o convertirlo en más útil o agradable. Se entiende que estas reparaciones y mejoras en bienes propios afecten el caudal social cuando tales bienes sean usufructuados por la sociedad conyugal, explicación que cubre también el pago de los tributos. Ahora bien, con mayor razón se entiende la calidad de deuda social cuando las reparaciones, mejoras, tributos y retribuciones afecten al bien que tiene la calidad de social.

5. Los atrasos o réditos devengados de las obligaciones a que estuviesen afectos los bienes propios y los sociales, cualquiera que sea la época a que correspondan. Se refiere a los intereses que rinde el capital no pagados a su vencimiento, y que el patrimonio social deberá satisfacer por el disfrute que efectúa de los mismos, independientemente de que sean propios o sociales. Repárese en que el legislador hace extensiva la norma incluso para aquellos atrasos que vienen de la época anterior a la constitución de la sociedad de gananciales. Sin embargo, termina siendo explicable la norma, en tanto que, como ya hemos visto, las deudas personales contraídas en beneficio de la familia se pagan en defecto de los bienes propios, con los bienes sociales.

6. Las cargas que pesan sobre los usufructuarios respecto de los bienes propios de cada cónyuge. Recordemos que estos bienes son usados y disfrutados por la sociedad, por lo que es justo que la sociedad soporte las mencionadas cargas que pesan sobre todo usufructuario. Sobre el particular solo mencionaremos que las cargas a las que alude la norma están referidas al pago de los tributos, rentas vitalicias y pensiones de alimentos que graven los bienes si fuere el caso, las reparaciones ordinarias y las extraordinarias.

7. Los gastos que cause la administración de la sociedad. Se refiere a aquellos gastos necesarios, por ejemplo, en la explotación normal de un negocio de la sociedad, el pago realizado a favor de la persona contratada para una administración especial de bien o bienes de la sociedad, lo gastado en la recuperación extra o judicial de un bien de la sociedad.

\subsection{Presunciones relativas a la naturaleza del bien}

Presumir es dar por cierto algo que es probable. En el caso de la calificación de los bienes dentro de una sociedad de gananciales, que se caracteriza precisamente por la coexistencia de bienes propios y sociales, se hace necesario trabajar con presunciones, en función principalmente a cautelar intereses de terceros que contratan con el o los cónyuges, y atendiendo a que a veces resulta difícil calificar un bien, pues no siempre se tiene referencias sobre su origen - fecha de adquisición o si se adquirió en forma graciosa u onerosa - o puede darse el caso de que la calidad del bien haya variado, ya que no siempre se mantiene en la misma condición. Por ello, y para garantía de terceros, se han establecido 
presunciones legales, y así el artículo 311 del Código Civil establece tres presunciones sobre la naturaleza de los bienes de la sociedad. Veamos:

1. Todos los bienes de los cónyuges se presumen sociales. Se parte de la premisa de que por tradición jurídica o costumbre, los peruanos y peruanas se han casado mayoritariamente bajo el régimen de sociedad de gananciales, siendo el de separación de patrimonios algo excepcional. En esa medida, y bajo el concepto de que el matrimonio une a las personas no solo en lo personal sino también en lo económico, es que el legislador peruano ha trabajado esta presunción de que todo lo adquirido dentro del matrimonio se presume social, salvo prueba en contrario, prueba que convierte esta presunción en una de juris tantum: esto es, presumimos que es un bien social, y quien desee enervar tal presunción, sobre él recaerá la carga de la prueba. Entonces, es una presunción que se puede atacar. Creemos que esto es un acierto sobre todo para facilitar las operaciones comerciales con terceras personas, debiendo precisar que si el bien se hubiera adquirido onerosamente a nombre de uno solo de los cónyuges, e incluso haciéndose pasar como soltero, no escapa de la presunción, en tanto no pruebe que lo adquirió con caudal propio. Por lo tanto, en este supuesto lo gravitante será la fecha de adquisición.

2. Los bienes sustituidos o subrogados a otros se reputan de la misma condición que los que se sustituyeron o subrogaron. Cambio de un bien por otro: si el bien cambiado tiene la calidad de propio, aquel que recibe en lugar del cambiado también tendrá la calidad de propio. La presunción permite que los bienes propios puedan ser sustituidos por otros (cambiados), conservando estos el mismo carácter de propios, con lo cual se impide que los bienes sustituidos tengan el carácter de sociales. Un caso típico de esta presunción lo encontramos en los bienes permutados.

3. Si se vende algún bien, cuyo precio no consta haberse invertido, y luego se compra otro equivalente, se presume que la adquisición posterior fue hecha con el producto de la enajenación anterior. Si el bien vendido tenía la calidad de propio, y con el producto de la venta (precio) se compra otro, es claro inferir que el nuevo bien comprado con el producto de la venta del primer bien, seguirá la misma suerte del bien vendido, esto es, será igualmente propio. Aparentemente, la norma es una especie de repetición de la presunción anterior, pues también estaríamos aquí en una sustitución de un bien por otro. Sin embargo, creemos que difiere de aquella por algunos elementos nuevos. Así, el primer bien ya salió del patrimonio de su titular, el mismo que ha recibido un precio por él. Por lo tanto, ese precio que se traduce en una cantidad de dinero tiene la condición de propio, y es ese dinero el que supuestamente se ha empleado en la compra del nuevo bien. 
Entonces ha habido una nueva sustitución, la del dinero por el bien adquirido, y si el dinero era propio, también será propio el bien adquirido con la entrega de ese dinero (pago del precio), salvo que se demuestre lo contrario, esto es, que el otro cónyuge acredite el destino del dinero recibido como producto de la venta del primer bien. Si ello es así, y si ese dinero sirvió para otras cosas diferentes a la adquisición del nuevo bien, entonces habrá destruido la presunción y el nuevo bien será social. Creemos que para que funcione esta presunción, debería estar presente otro elemento: la contemporaneidad entre la venta y adquisición del nuevo bien. En la práctica puede acontecer que el bien vendido, que tenía la calidad de propio, se haya verificado por una determinada suma, y el nuevo bien comprado exceda la suma recibida por la venta del primer bien. En ese caso, el bien debería ser considerarlo mixto, reputándose la diferencia del precio del segundo bien comprado con respecto a la venta del primero, como social.

\subsection{Fin de la sociedad de gananciales}

Como dice Arias Schreiber Pezet Max, el fenecimiento de la sociedad de gananciales tiene un doble propósito: poner fin a la sociedad de gananciales y repartir sus ganancias si las hubiere, después de deducidas las cargas y deudas sociales. Ahora bien, nace el régimen de sociedad de gananciales por el matrimonio, siempre y cuando no se haya optado por la separación de patrimonios. En consecuencia, el régimen estará vigente, de ordinario, mientras dure el matrimonio, salvo que convencionalmente se cambie de régimen, o como consecuencia de una sentencia en un juicio de separación de patrimonios, o se produzca una separación legal. Por lo tanto, el fin de la sociedad de gananciales deberá ocurrir cuando ya no exista matrimonio, y no existirá por muerte de uno de los cónyuges, por divorcio o por invalidación del matrimonio. Algunos supuestos de término de la sociedad debemos considerarlos como ordinarios, tal es el caso de la muerte de uno de los cónyuges, o extraordinarios, como sería el caso de la ausencia de un cónyuge.

Habiendo mencionado que la sociedad de gananciales se inicia con el matrimonio, lógico es entonces que cuando desaparezca el matrimonio termine la sociedad, y en efecto, esta fenece por muerte de uno de los cónyuges, divorcio o invalidación del matrimonio.

Hay casos excepcionales en que estando aún vigente el matrimonio, termina la sociedad de gananciales. Ellos son: el cambio de este régimen patrimonial por el de separación de patrimonios; la separación legal, sea por causal o por separación convencional; y cuando estamos frente a la declaración judicial de ausencia de uno de los cónyuges, pues con la ausencia desaparece el fundamento de la comunidad de intereses en la sociedad conyugal. Ahora bien, los 
elementos que configuran la ausencia son: la desaparición; el transcurso de dos años desde las últimas noticias que se tuvo del desaparecido; y la resolución judicial que declara la ausencia. En lo que atañe a esto último, interesa la fecha de esta resolución, pues con ella se produce el fin de la sociedad de gananciales. Concluido el régimen, y tal como lo veremos, se procede a la liquidación de este patrimonio social.

Tenemos que tener en cuenta igualmente la ley 27809 que modificó el artículo 330 del Código Civil, pues estamos en presencia de otro supuesto de término de la sociedad: cuando se declara la insolvencia de uno de los cónyuges. Cuando esto ocurre, de pleno derecho se produce el fin de la sociedad de gananciales y su cambio por el de separación de patrimonios, debiendo inscribirse en el registro personal de oficio para que surta efectos frente a terceros.

Para los terceros, el régimen de comunidad de gananciales solo se considera fenecido en la fecha de inscripción pertinente en el registro personal.

\subsubsection{Fecha de fenecimiento del régimen de sociedad de gananciales}

Tanto para los cónyuges como principalmente para los terceros, interesa saber desde qué momento surte efectos el fenecimiento del régimen. Recordemos sobre el particular que al desaparecer el régimen, se pasa a uno de completa separación de patrimonios, y en consecuencia, ambos cónyuges quedan libres para poder celebrar actos jurídicos sobre los bienes cuya titularidad han adquirido individualmente; así mismo, la garantía de los terceros que con pleno conocimiento sabrán con quien están contratando. Estas razones han llevado a que el legislador señale en forma pormenorizada el momento preciso en el que ha terminado este régimen.

En efecto, el artículo 319 del Código Civil nos señala que para las relaciones entre los cónyuges, el fenecimiento se considera producido en la fecha de la muerte del cónyuge, pues como sabemos, al producirse el deceso de uno de los cónyuges ya no hay matrimonio, y por lo tanto, se da paso a la liquidación de la sociedad de gananciales, y a la vez, según normas de derecho de sucesiones, se abre la sucesión del cónyuge muerto. También se ha considerado a la declaración de muerte presunta como causa de fenecimiento de la sociedad, en atención a que tienen los mismos efectos que la muerte biológica. Por lo tanto, será la fecha de la declaración de muerte presunta el referente importante para conocer el momento del fenecimiento de la sociedad. Concluye igualmente el régimen en la fecha de la declaración de ausencia del cónyuge, procediéndose a liquidar la sociedad así como a entregar provisionalmente los bienes del ausente a los que resulten ser sus herederos forzosos, dentro de los cuales está el cónyuge. En el caso de divorcio, separación legal, invalidación de matrimonio o cambio de régimen judicial, fenece el régimen de sociedad de gananciales a 
partir de la notificación al otro cónyuge con la demanda respectiva, y ello es así a fin de evitar que cualquiera de los cónyuges se aproveche de la duración del juicio para continuar con los beneficios del régimen. Sin embargo, y a propósito de la ley 27495, tratándose de la separación legal o divorcio por la causal de abandono injustificado de la casa conyugal y la de separación de hecho, el régimen de sociedad de gananciales concluye, cuando se produce la separación de hecho, lo que torna de suma importancia acreditar cuándo se dejó de vivir juntos. Sin embargo, esta modificación que es de gran trascendencia ha sido incluida en el Código sin reparar que ya existía una norma que castiga al cónyuge que se separa del domicilio conyugal, privándolo de sus gananciales en proporción al tiempo que ha durado su alejamiento del hogar conyugal, tema del cual nos ocuparemos más adelante. Si se ha producido cambio de régimen patrimonial consensual, el régimen de sociedad de gananciales termina en la fecha de la escritura pública correspondiente. Aparentemente, se deja de lado la inscripción registral, lo cual puede dar lugar a problemas en la adquisición de bienes en el intervalo entre la escritura pública y su registro, sobre todo tratándose de terceros. Por ello, la propuesta de reforma del libro de familia del Ministerio de Justicia aclara que en la sustitución de un régimen por otro no solo es necesario el otorgamiento de escritura pública, sino que para que surta efecto ante terceros, debe inscribirse en el registro personal.

\subsubsection{Procedimiento de liquidación}

Disuelta la sociedad de gananciales, bien automáticamente, bien por resolución judicial, procede liquidarla, a cuyo efecto primero se inventaría su activo y pasivo, después se pagan las obligaciones sociales, luego se devuelven los bienes propios, y por último, el saldo activo que queda se distribuye entre los cónyuges, o entre el que de ellos sobreviva, y lo que hubiera correspondido al cónyuge muerto, constituye su patrimonio hereditario, llamándose a sus herederos, dentro de los cuales se encuentra el cónyuge sobreviviente. En este último caso las normas que se deben aplicar son las del derecho sucesorio.

No basta que haya operado el fenecimiento de la sociedad de gananciales por cualquiera de los supuestos ya estudiados, sino que se hace indispensable ir al proceso de liquidación, en tanto que la disolución de la sociedad de gananciales origina una situación jurídica en la que hay un patrimonio indiviso regido por las reglas de la copropiedad, situación jurídica que permanecerá inalterable mientras no se solicite la liquidación. Al finalizar la sociedad de gananciales, pueden pedir la liquidación cualquiera de los titulares del patrimonio social, e incluso decimos, aquel que tenga legítimo interés estaría facultado para ello. Recordemos sobre el particular, que al finalizar la sociedad de gananciales nos encontramos ante una copropiedad, y en tal mérito y con 
normas de la copropiedad, cualquiera de los copropietarios puede solicitar su liquidación, facultad que se extiende también a los acreedores, Una situación similar ocurre con la masa hereditaria indivisa, en la que cualquier coheredero puede pedir la partición de la herencia indivisa, y también los acreedores de la sucesión o acreedores de los herederos.

Resulta ilustrativa al respecto, la resolución casatoria 848-96 que señala la improcedencia de la pretensión de partición de un bien adquirido, en vigencia del matrimonio extinguido por divorcio, sin que antes se solicite la liquidación patrimonial de la sociedad de gananciales, la cual tiene su inicio con el inventario de los bienes, el pago de las obligaciones sociales y cargas, el reintegro a cada cónyuge de los bienes propios que quedaren y que se dividan por mitad los gananciales remanentes.

Para proceder a la liquidación del patrimonio social, el legislador ha considerado necesario una serie de pasos que comenzamos a analizar.

\section{a) Inventario}

Siguiendo al artículo 320 del Código Civil, el primer paso que encontramos como inicio de la liquidación es el inventario de todos los bienes del régimen y también de las deudas sociales. Pues bien, el inventario no es otra cosa que una relación detallada de todo el activo y pasivo de la sociedad de gananciales. Aquí deben considerarse tanto los bienes propios de los cónyuges existentes al momento de la liquidación como los sociales. Ahora bien, este inventario no requiere ser judicial, el cual solo será necesario si las partes no están de acuerdo; si existe consenso, basta el documento privado con una firma legalizada. Es necesario que en este inventario conste el valor de cada bien para facilitar la partición. Por disposición expresa del legislador, no se incluyen en el inventario los bienes que constituyen el menaje ordinario de la casa, los mismos que quedan en poder del viudo o viuda (si la sociedad feneció por muerte de uno de los cónyuges o declaración de muerte presunta), o del cónyuge del ausente (si la sociedad terminó por declaración judicial de ausencia). Sobre el particular creemos justificada la disposición a fin de no despojar de los muebles, enseres o utensilios domésticos que fueron de uso diario en el hogar conyugal. Debe tenerse en cuenta para una mejor comprensión de la norma, qué bienes están excluidos del menaje, destacándose entre ellos, el dinero, los títulos valores, las joyas, los vehículos motorizados, y en general, los objetos que no son de uso doméstico.

b) Pago de las obligaciones sociales y de las cargas

Al estudiar el pasivo del patrimonio social, analizamos las deudas personales que pueden comprometer el patrimonio social, las deudas sociales en razón de 
haber sido asumidas en beneficio de la sociedad, y las cargas u obligaciones que soporta la sociedad de gananciales y que se hayan descritas en el numeral 316 del Código Civil. Pues bien, son estas obligaciones existentes al momento de la liquidación, las que tendrán que ser pagadas prioritariamente, y deberán serlo con el patrimonio social. Incluso si este patrimonio fuera insuficiente o no existe, dichas deudas sociales terminan afectando los bienes propios de los cónyuges a prorrata, y si solo uno de ellos tuviera bienes propios, se verá perjudicado pues dichos bienes serán destinados a pagar las deudas sociales. Un problema que hay que resolver es el hecho de que durante la vigencia de la sociedad de gananciales, se hayan pagado deudas sociales con bienes propios de uno de los cónyuges, en atención a que en el momento de la exigibilidad de la obligación, no había o eran insuficientes los bienes sociales y por ello se vio comprometido el bien propio del cónyuge. En ese caso, llegado el momento de la liquidación, surge la interrogante del reembolso a favor de aquel cónyuge que en exclusividad pagó la deuda. Sobre el particular, y pese a que no existe norma sobre el tema, creemos que por equidad y justicia se debería dar paso al reembolso, si es que obviamente existieran bienes propios del otro cónyuge que se benefició con el pago de su consorte. En consecuencia, una vez formalizado el inventario, se procede a pagar estas deudas y obligaciones y cargas sociales.

c) Reintegro a cada cónyuge de sus bienes propios

Habiéndose honrado las obligaciones sociales y si quedaren bienes propios, estos deberán ser devueltos a sus titulares en atención a que como ya ha quedado claro, tales bienes no cambian de titular: sin perjuicio de que hayan estado destinados a uso de la sociedad conyugal, no pierden su condición de propios. Por ello, refiere el artículo 322 del Código Civil que dichos bienes retornan a sus propietarios, quienes reciben los bienes en la condición en que se encuentren. Al respecto, se debe tener en cuenta que la legislación ha pormenorizado los bienes propios, y si hubiera dudas sobre la calidad de los mismos, existen las presunciones que también han sido detalladas. En todo caso, será el cónyuge que se sienta perjudicado con la calificación de un bien propio como social, el que deba demostrar que le pertenece en exclusividad.

d) Distribución de gananciales

Habiéndose pagado las deudas sociales, y efectuada la devolución de los bienes propios, si aún quedan bienes, derechos, entonces, ese remanente o saldo toma el nombre de gananciales. Alude a los bienes que se ganan o aumentan durante el matrimonio por el trabajo de los cónyuges, por los frutos y productos de los bienes propios y sociales y por otros títulos legales. 
Presten atención al término de gananciales que da el nombre precisamente a esta comunidad de bienes. Son estos bienes los que los ex cónyuges se dividen por mitades, o si la sociedad termina por muerte de uno de los cónyuges, el sobreviviente recibe su mitad, y la otra viene a ser la masa hereditaria dejada por el causante. En cuanto a si la distribución de gananciales constituye una mutua transferencia de derechos entre los cónyuges, resulta interesante la resolución casatoria 837-97, que refiere que al constituir la sociedad de gananciales un ente jurídico autónomo no sujeto a un régimen de copropiedad, la adjudicación de gananciales a cada cónyuge no constituye una mutua transferencia de derechos entre ellos, sino que tal transferencia es efectuada por la mencionada sociedad de gananciales que se está liquidando. Habría que decir sobre el particular, que la sociedad de gananciales ya no existe como tal en razón de su extinción, y que más bien lo que existe es una copropiedad, y en esa medida consideramos que estaríamos ante una permuta de derechos, tal como sucede con la partición de una masa indivisa.

\subsubsection{Normas complementarias sobre liquidación}

a) Preferencia para la adjudicación de la casa conyugal

Refiere el tercer párrafo del artículo 323 del Código Civil que cuando la sociedad de gananciales ha fenecido por muerte o por declaración de ausencia de uno de los cónyuges, el otro tiene preferencia para la adjudicación de la casa en que habita la familia y del establecimiento agrícola, artesanal, industrial o comercial, de carácter familiar, con la obligación de reintegrar el exceso de valor si lo hubiera.

Este derecho preferencial de adjudicación descansa en dos supuestos. El primero es que solo juega en el caso del fin de la sociedad de gananciales por muerte de uno de los cónyuges, a la que debe agregarse la declaración de muerte presunta, y en el caso de declaración judicial de ausencia. El segundo supuesto se refiere a que este derecho preferencial se aplica sobre el inmueble que sirvió de hogar conyugal, lo que no implica que no existan otros inmuebles; por lo tanto, alude a la casa habitación en donde vivió la sociedad conyugal y donde se desarrolló la familia. El derecho, por lo tanto, está destinado a favor del cónyuge sobreviviente, o del cónyuge del ausente, lo que supone una excepción más al derecho de los herederos para solicitar partición respecto de ese inmueble. Ahora bien, este derecho preferencial de adjudicación deberá ser cubierto por el cónyuge supérstite, o cónyuge del ausente, con los derechos que le corresponden a título de gananciales más su cuota hereditaria; si la suma de ellos alcanza el valor del inmueble en el que habitó la sociedad conyugal, entonces se podrá hacer efectivo la adjudicación, pero si no alcanzara y no 
tuviera la posibilidad de cubrir la diferencia del valor del inmueble con la suma de sus gananciales y cuota hereditaria, podrá ejercer su derecho de habitación vitalicio, tal como lo regula el artículo 731, numeral este ubicado en sede de sucesiones.

Este derecho preferencial de adjudicación del inmueble que sirvió de hogar conyugal lo hace extensivo el legislador al establecimiento agrícola, artesanal, industrial o comercial de carácter familiar. En otras palabras, lo que está queriendo decir el legislador es que también el viudo o viuda, o el cónyuge del ausente, tiene derecho a adjudicarse el patrimonio familiar, figura esta que, como sabemos, existe en función de proteger a la familia, garantizando que el predio en que existe la casa habitación o el comercio, industria, artesanía o agrícola no pueda ser embargado, hipotecado o vendido. Sin embargo, confunde el legislador, en tanto que el patrimonio familiar no puede ser adjudicado a nadie mientras existan beneficiarios del mismo, habiendo previsto la ley formas para su extinción, dentro de las cuales, ciertamente, no está esta figura de la adjudicación, y no podría estarlo por cuanto se trata de que ese predio permanezca en esa situación de afectación a favor de los beneficiarios del patrimonio, entre los cuales no solo está el cónyuge sino también otros parientes, tal como se ve en el capítulo respectivo de la institución del patrimonio familiar. Por lo tanto, legalmente no resulta procedente, en atención a que el patrimonio familiar subsiste, aun cuando se produzca la muerte del constituyente, si es que le sobreviven beneficiarios.

\section{b) Pérdida de gananciales por separación de hecho}

El artículo 324 del Código Civil nos señala cómo proceder en el caso de la separación de hecho de uno de los cónyuges, estando en vigencia el régimen de gananciales. En este caso, el cónyuge culpable pierde su derecho a gananciales proporcionalmente a la duración de la separación. Obviamente, se trata de una sanción a aquel cónyuge que sin justificación alguna se aparta de la sociedad conyugal, la misma que como ya hemos señalado, queda administrada ahora por el cónyuge abandonado. El cónyuge que permanece en el hogar conyugal, es ahora el que se encarga de hacer producir los bienes de la sociedad. En esa medida sería injusto, llegado el momento de la liquidación, que el cónyuge abandonante se presente a reclamar gananciales generados por el que estuvo al frente del patrimonio social. Por ello, se señala que el abandonante pierde sus gananciales proporcionalmente al tiempo en que se apartó del hogar conyugal. Sin embargo, esta norma termina siendo modificada tácitamente por la ley 27495, que indica que en los casos de abandono y separación de hecho, el término de la sociedad de gananciales se produce en el momento en que se da tal separación. Esto significa que la sociedad de gananciales terminará 
el día en que el cónyuge se apartó del domicilio conyugal, con lo cual la norma que estamos comentando prácticamente se hace inoperante. Si ya concluyó la sociedad de gananciales, a qué gananciales nos referimos cuando la sociedad como tal dejó de serlo, y por lo tanto lo que existe es una copropiedad; en esa medida, si el cónyuge copropietario hace producir el bien, sus frutos serán no solo de aquel que los produjo sino también del otro copropietario. Esto resulta obviamente injusto, por ello reclamamos nuevamente la plena vigencia del artículo 324.

\subsubsection{Liquidación simultánea de varias sociedades de gananciales}

Lo normal y ordinario es que cuando una sociedad de gananciales ha concluido, deba liquidarse bajo las reglas ya estudiadas. Sin embargo, puede acontecer - y por ello el legislador regula el supuesto- que concluido un matrimonio no habiéndose liquidado la sociedad de gananciales, surge un nuevo matrimonio bajo el régimen de sociedad de gananciales, el cual una vez concluido debe liquidarse. Entonces estamos ante dos sociedades de gananciales — pueden ser más de dos- que deben ser liquidadas. En ese caso, se dictan pautas a fin de no perjudicar a nadie, y así si no hubiera inventario de cada una de las sociedades, se admitirá toda clase de pruebas para acreditar los patrimonios sociales de uno y otro. Y si no hubiera certidumbre para separar los patrimonios, la regla a aplicar es la de dividir los gananciales — en el caso de que los hubieraentre las diferentes sociedades, teniendo como criterio determinante el tiempo de duración de cada una de las sociedades. Estas reglas parten del supuesto de que el matrimonio que tuvo mayor duración tuvo la posibilidad de generar mayores bienes sociales, y en esa medida le corresponderá mayores gananciales que el matrimonio que menos duró.

\section{Régimen de separación de patrimonios}

Como sabemos, con la legislación anterior solo existía el régimen de sociedad de gananciales, el mismo que operaba automáticamente por el hecho del matrimonio. No había opción pues había un único régimen. Es cierto que se previó la separación de bienes, pero solo como resultado de un proceso judicial por un abuso de las facultades de administración que causaba perjuicio al otro.

El vigente Código Civil de 1984 otorga a los futuros contrayentes la posibilidad de escoger entre el régimen de sociedad de gananciales o el de separación de patrimonios. Esta posibilidad sigue existiendo durante el matrimonio, y en las oportunidades que los cónyuges deseen, bastando solo el acuerdo de ambos, debiendo precisarse que no se ha dejado de lado la separación de bienes, como resultado del proceso judicial por perjuicio económico al cónyuge solicitante. 
El régimen de separación de patrimonios no implica un decaimiento del vínculo matrimonial, el mismo que se mantiene con todos los derechos y deberes que nacen del matrimonio. Sobre el particular, el artículo 300 del Código Civil refiere que cualquiera que sea el régimen en vigor, ambos cónyuges están obligados a contribuir al sostenimiento del hogar según sus respectivas posibilidades y rentas.

Lo que caracteriza al régimen de separación de patrimonios no solo es que cada cónyuge conserva la propiedad de sus bienes, sino que también conserva la administración y disposición de los mismos. En consecuencia, los cónyuges adquieren, disfrutan y disponen de sus bienes sin limitación alguna, como si no estuvieran casados. Los frutos de los bienes de cada cónyuge le corresponden al titular del bien. En este régimen excepcional, todos los bienes que adquieran los cónyuges por cualquier concepto, sea gracioso u oneroso, durante la vigencia del matrimonio, ingresan a sus respectivos patrimonios, de tal forma que pueden ejercer todos los actos inherentes al dominio.

En cuanto a las deudas en el régimen de separación de patrimonios, cada cónyuge que ha contraído una deuda debe responder por ella con su propio patrimonio, no comprometiendo para nada al otro cónyuge.

Como es natural, el régimen de separación de patrimonios puede afectar a terceros, especialmente cuando se ha llegado a él dentro del matrimonio por cambio de régimen, esto es, cuando se ha pasado de un sistema de sociedad de gananciales a otro de separación de patrimonios. En esa medida, la ley exige la inscripción del régimen en el registro personal, que debe entenderse como registro personal de cada cónyuge.

A propósito del estudio de la sociedad de gananciales, señalamos que este sistema fue el único en los códigos civiles de 1852 y 1936. Por lo tanto, es un régimen que se ha entronizado en el alma del pueblo peruano y no llama la atención de que la gran mayoría de los matrimonios civiles que se contraen o de los que ya existen estén bajo ese régimen y sólo una minoría haya optado por el de la separación de patrimonios. Sobre el particular, resulta ilustrativa una información registral de Lima y Callao que abarca desde 1984 —el 14 de noviembre de 1984 entró en vigencia el presente Código Civil— hasta julio de 1995 y que arrojó los siguientes resultados: 2581 separaciones de patrimonio, y de esta cifra 527 fueron antes del matrimonio, es decir entre novios, y 2054 durante el matrimonio, esto es, ya entre cónyuges; por otro lado, se detectaron 228 casos de separaciones judiciales de bienes. Pues bien, estos números nos indican que no ha habido una aceptación importante de la separación de patrimonios, muchos dicen que por la poca difusión del sistema. Ello puede ser cierto, pero también habría que buscar las causas, tal como dijimos, en la idiosincrasia del pueblo peruano que ve el matrimonio como una fusión de personas, una entrega total, en la que la comunidad debe darse tanto en lo 
personal como en lo económico y en la que una separación de bienes atentaría contra esa comunión.

Se ha señalado que el régimen de separación de patrimonios es el régimen de bienes en el matrimonio que menos se identifica con la institución matrimonial, ya que establece en el campo patrimonial, un sistema según el cual los cónyuges disponen de sus bienes como si no estuvieran unidos en matrimonio. Por otro lado, no es menos cierto que otorga una gran protección a los cónyuges, lo que no necesariamente ocurre en el régimen de la sociedad de gananciales, en donde los cónyuges pueden cometer abusos en la administración y disposición de los bienes, aun cuando esto último es relativo por la administración y disposición conjunta de los bienes sociales. Por otro lado, hay que considerar que el régimen de separación de patrimonios puede desfavorecer al cónyuge que se dedica al cuidado del hogar y de los hijos y que por lo tanto no genera ingresos reales en tanto que no se dedica a un trabajo, oficio, industria. Al no generar ingresos propios, aunque preste apoyo al otro cónyuge dentro del hogar, su patrimonio no se incrementará, y nada de lo que adquiera el otro cónyuge le corresponderá, pues en este régimen nada se comparte sino que todo está dividido.

Por lo excepcional del régimen, pues lo común es que los que se casan o los que ya están casados adopten el régimen de sociedad de gananciales, para optar por el régimen de separación de patrimonios constituye un requisito formal bajo sanción de nulidad, el otorgamiento de escritura pública y la inscripción en el registro personal. En consecuencia, si no se ha cumplido con esta exigencia formal ad-solemnitatem no habrá separación de patrimonios.

El régimen de separación de patrimonios por cambio de régimen, esto es, cuando se pasa de uno de sociedad de gananciales al de separación, implica obligatoriamente la liquidación de aquel y la inscripción en el registro. En caso contrario, tampoco habrá separación.

En lo que se refiere a los casos en que se llega al régimen de separación de patrimonios, debemos señalar que procede antes del matrimonio y aun dentro del matrimonio. Veamos por separado cada uno de ellos.

\subsection{Régimen de separación antes del matrimonio}

Los novios son libres de elegir el régimen económico que gobernará sus intereses económicos en el futuro matrimonio, elección que se da entre dos regímenes: el de la comunidad de bienes y el de la separación de patrimonios. Pues bien, si eligen este último, necesariamente deberán otorgar escritura pública bajo sanción de nulidad e inscribir en el registro personal, comenzando a producir efectos el régimen de separación cuando se celebre el matrimonio. Esto último supone su inexistencia si no se llegara a celebrar el matrimonio, pues el 
acto matrimonial viene a jugar como una suerte de condición suspensiva; verificada ella, el acto comienza a producir efectos. Ahora bien, no es necesario que cuando los novios opten por el régimen de separación tengan bienes presentes: de lo que se trata es de elegir el régimen a futuro que gobernará el matrimonio.

Elegido el régimen, este comprende los bienes presentes que tengan los novios cuando celebran el acto matrimonial y los bienes futuros que adquieran dentro del matrimonio. Para los efectos patrimoniales, el matrimonio no tiene mayor implicancia o relevancia. En consecuencia, los bienes corresponderán a aquel cónyuge que en su estado de soltería los adquirió. Así mismo, los bienes que adquirirá dentro del matrimonio también le corresponderán, y no solo los bienes, sino también sus frutos, productos del bien, pues en este régimen no se comparte nada; y si esto es así con respecto de los bienes, también lo es con respecto de las deudas que existían antes de casarse y las que se contraerán dentro del matrimonio. En consecuencia, serán de exclusiva responsabilidad de quien los hubiera contraído, no teniendo mayor implicancia con respecto del patrimonio del consorte, el cual ha quedado totalmente desligado del otro.

Otra de las razones que se ha dado para señalar el poco uso de este régimen antes del matrimonio, es el excesivo rigor formal con su ineludible costo, pues es necesario la minuta, la escritura pública y la inscripción en el registro. Ahora bien, el proyecto de reforma del libro de familia del Ministerio de Justicia aboga por la posibilidad de que la elección del régimen se dé igualmente en el acto de la celebración del matrimonio, correspondiendo al alcalde o el que haga sus veces, levantar acta de ello y luego cursar los partes al registro personal. La propuesta, que ya había sido formulada en varios eventos, implica una labor de difusión de los regímenes económicos del matrimonio, con la finalidad de que cuando se celebre el matrimonio, los contrayentes estén en la posibilidad real de optar por uno de ellos y no suceda que cuando el alcalde o el que haga sus veces pregunte por la elección, ellos no sepan qué responder, o lo que es peor, elijan sin conocer las características de cada uno de los regímenes.

\subsection{Régimen de separación dentro del matrimonio}

Supone un matrimonio celebrado bajo el régimen de sociedad de gananciales, el cual por las razones que se comentan a continuación deviene en separación de patrimonios. Veamos.

\subsubsection{Separación de patrimonios bajo concierto}

Se ha dejado establecido que con el Código Civil vigente, la posibilidad de cambiar de régimen puede deberse a un acto que responde a un concierto 
voluntario de los cónyuges, quienes sin expresar causa alguna pueden variar de régimen. Sin embargo, para que ello se produzca es obligatorio, en primer lugar, liquidar el régimen de sociedad de gananciales que van a dejar atrás, un proceso de liquidación que debe respetar las normas legales que ya hemos analizado. Luego se procede a la inscripción en el registro personal. Cabe notar que como se trata de un acuerdo de voluntades entre personas capaces, pueden libremente convenir en asumir deudas, adjudicarse bienes, condonarse obligaciones, y lo que es más importante y que debiera ser siempre parte inherente a cualquier acuerdo de separación, establecer el régimen alimentario que regirá la sociedad conyugal, mencionándose los alimentos entre los cónyuges, o la decisión que acuerden sobre el particular, y los alimentos de los hijos comunes, pues de no figurar ello en el acuerdo y surgir discrepancias sobre la forma de cumplir con estas obligaciones, tendrá que ser el juez quien termine reglándolo.

\subsubsection{Separación de patrimonios por decisión judicial}

Implica el abuso de facultades de administración de los bienes sociales por parte de uno de los cónyuges que causa perjuicio al otro. Este abuso puede deberse a una disposición inconsulta de bienes sociales, a una mala administración que pone en peligro los bienes sociales o a no compartir los frutos de los bienes propios o sociales con el otro cónyuge. Esto da lugar a que estando bajo el régimen de sociedad de gananciales, se recurra al juez para que en un proceso civil abreviado se determine el cambio de régimen, lo que igualmente supone la previa liquidación del régimen de sociedad y su inscripción en el registro. Es importante tener en cuenta que, en este supuesto, la fecha del fenecimiento del régimen de sociedad de gananciales es la fecha de notificación de la demanda de separación, para evitar abuso de parte del cónyuge demandado aprovechando la demora del proceso, y que proceden las medidas cautelares para salvaguardar el patrimonio social.

La propuesta de reforma del libro de familia del Ministerio de Justicia, a la que ya hemos aludido, sugiere que se incluyan otras dos causales para la procedencia de la separación de patrimonios por decisión judicial: la interdicción de uno de los cónyuges y la condena por delito doloso. Sobre el particular, mostramos nuestra disconformidad, en especial con la declaración de interdicción, por atentar directamente con el deber de asistencia que impone el matrimonio a los cónyuges. En efecto, si el matrimonio está sometido al régimen de sociedad de gananciales, y uno de ellos deviene en interdicción, lo que debe ocurrir es que el cónyuge del interdicto, que ocupa la curatela, vele por los intereses del curado, y así estará velando también por los intereses de la sociedad. Si ocurriera lo contrario, estaríamos introduciendo un elemento disociador en la sociedad conyugal, pues se le estaría posibilitando al cónyuge capaz, 
automáticamente a separar sus bienes del incapaz, no encontrando explicación para ello; obsérvese que se actúa sobre la base del interés particular antes que del interés familiar. En cuanto a la condena por delito doloso, habría que estar a la clase de condena, pues como sabemos existen condenas suspendidas, o condenas sin carcelería efectiva, y en todos esos casos el cónyuge sigue al frente de sus intereses, dentro de los cuales obviamente está la sociedad de gananciales de la cual él forma parte. Por otro lado, no olvidemos que existe la separación de patrimonios convencional si es que los cónyuges desean cambiar de régimen. En cuanto a la propuesta de que la separación de patrimonios surta efectos desde que quede consentida o ejecutoriada la sentencia, puede resultar peligrosa, pues con ello se estaría dando la posibilidad de que el cónyuge malicioso pueda usar malas artes durante todo el proceso que se sigue hasta llegar a la sentencia. Por ello considero que lo que está vigente, esto es que entre los cónyuges la separación del régimen económico surte efectos a partir de la notificación con la demanda, es lo más aconsejable.

\subsubsection{Cambio de régimen por procedimiento concursal}

El artículo 14 de la ley concursal que regula el patrimonio comprendido en el concurso - el concurso hace referencia a una situación de concurrencia de acreedores sobre un patrimonio que resulta insuficiente para satisfacer el total de obligaciones que afronta su titular como deudor-, establece que aquel deudor, persona natural que desee ingresar a un procedimiento concursal y cuyo patrimonio se encuentre sujeto al régimen de sociedad de gananciales, deberá sustituir dicho régimen por el de separación de patrimonios, constituyendo este trámite previo un requisito de admisibilidad de la solicitud. Se entiende que lo que busca la ley es poder identificar claramente los bienes que integrarán el patrimonio del deudor sometido a concurso. Por otro lado, la quinta disposición transitoria de la Ley de Reestructuración Patrimonial, decreto legislativo 845, ha modificado el artículo 330 del Código Civil, en el sentido de que la declaración de insolvencia de uno de los cónyuges determina de pleno derecho la sustitución del régimen de sociedad de gananciales por el de separación de patrimonios, y para que produzca efectos frente a terceros, se inscribirá en el registro personal de oficio, a solicitud del insolvente, de su cónyuge o del administrador especial.

\subsection{Fenecimiento del régimen de separación de patrimonios}

Si la opción del régimen de separación de patrimonios se da dentro del contexto de un matrimonio, lógico es que termine cuando desaparezca el matrimonio. En efecto, ello ocurre cuando se declara la invalidez del matrimonio o 
cuando este termina por muerte de uno de los cónyuges o por un divorcio. Sin embargo, en forma excepcional puede terminar aún cuando el matrimonio se halla vigente, lo que acontece cuando los cónyuges deciden libremente cambiar el régimen de separación de patrimonios por uno de sociedad de gananciales. En este caso, tal variación sí requiere de inscripción en el registro, pues no olvidemos que en dicho registro, figuran los cónyuges, con un régimen económico de separación de patrimonios; en consecuencia, no solo para los intereses de ellos sino en mayor medida para garantía de los terceros, deberá inscribirse el nuevo régimen de sociedad de gananciales en el registro personal.

\section{COMUNIDAD DE GANANCIALES EN CASO DE CONCUBINATO}

El artículo 5 de la Constitución del Estado ha reconocido al concubinato strictu sensu, en sentido estricto, un estatus jurídico legal. El artículo 326 del Código Civil lo describe como la unión de hecho, voluntariamente realizada y mantenida por un varón y una mujer, libres de impedimento matrimonial para alcanzar finalidades y cumplir deberes semejantes a los del matrimonio. Siempre según el código, esa unión origina una sociedad de bienes que se sujeta al régimen de sociedad de gananciales en cuanto le fuere aplicable, siempre que dicha unión haya durado por lo menos dos años continuos y no exista impedimento matrimonial entre los concubinos.

El concubinato como fenómeno social con consecuencias jurídicas aparece recién con la Constitución de 1979, y ello a propósito de una especie de reclamo popular ante los abusos existentes y que no pudieron ser atendidos judicialmente por falta de normas. En efecto, antes de 1979, los concubinatos que terminaban por decisión unilateral de uno de ellos, entiéndase abandono, no eran vistos por la magistratura como tales, recurriendo a calificarlos como sociedades de hecho, otros, señalando el camino del enriquecimiento indebido o sin causa, a fin de proteger particularmente a la concubina abandonada, la misma que había sido despojada de los bienes adquiridos dentro del concubinato, e incluso expectorada del hogar convivencial. La Constitución de 1979 y la de 1984 equiparan la sociedad de bienes nacida en el concubinato a la sociedad de gananciales originada en el matrimonio: equiparar significa equivalente, igual. En este caso, esa sociedad de bienes es equivalente o igual a la sociedad de gananciales, lo que implica que la normatividad que regula esta última, debe ser aplicada a la sociedad de bienes generada en la unión de hecho, no solo en cuanto a la calificación de bienes sino también en cuanto a las deudas, y lo que es más importante, en cuanto a la liquidación de la sociedad. Pero hay que tener en cuenta que no son aplicables a este régimen, por obvias razones, las reglas referentes al fenecimiento de 
la sociedad de gananciales producido por el divorcio, la separación legal y el cambio de régimen. Las demás disposiciones sí le serán aplicables.

Esta equiparidad solo se da cuando el concubinato tiene no menos de dos años de vida en común y cuando entre los concubinos no existen impedimentos matrimoniales. En este supuesto cabe demandar liquidación de la sociedad de bienes, pero previamente debe haber sido acreditado el concubinato en sede judicial, ya que como sabemos, no tenemos normas referidas al registro de los concubinatos. Ahora bien, cabe que en un solo proceso judicial se demanden el reconocimiento del concubinato, para lo cual se tendrá que aportar todo tipo de pruebas, y la liquidación de la sociedad de bienes generados en el concubinato. Sobre el particular resulta interesante transcribir esta parte de la resolución casatoria 1620-98: «[...] para que la concubina tenga derecho a darse por constituida la sociedad de gananciales como si existiera matrimonio civil, y que a su vez tenga derecho al cincuenta por ciento de los bienes constituidos por dicha sociedad, debe expresamente acreditarse el concubinato, con los requisitos de ley y contar con la decisión jurisdiccional de haberse constituido conforme a ley $[\ldots] »$.

El legislador también se ha puesto en el caso del concubinato irregular, aquel que no cumple con las exigencias de la falta de impedimento o de la vida en común no menor de dos años. En esos supuestos, al no poderse equiparar la sociedad de bienes a la sociedad de gananciales, queda el recurso al concubino perjudicado de accionar por enriquecimiento indebido. Sobre el particular, mencionamos la resolución casatoria 5-95 que señala que la acción de enriquecimiento sin causa tiene como finalidad proteger a un conviviente de los abusos y de las apropiaciones ilícitas del otro; en tal sentido, termina amparando el derecho del conviviente sobre un inmueble adquirido cuando las partes tenían una unión de hecho, aunque esta no haya generado una sociedad de gananciales.

En consecuencia, creemos que las normas que se refieren a la calificación de los bienes propios y sociales, y sus correlatos, las deudas personales y sociales, así como los procesos de término de la sociedad —excepto los ya mencionados - y la liquidación de la sociedad de gananciales, todo ello puede aplicarse a la sociedad de bienes que nace con el concubinato.

Repárese que en el presente el único derecho que tienen los concubinos es el comentado, pues no existen otros derechos — como el patrimonio familiar, el derecho de habitación, el derecho de usufructo, la herencia-, salvo el de alimentos, pero solo cuando el concubinato ha terminado por decisión unilateral de uno de ellos. El tema del reconocimiento de derechos similares a los del matrimonio para los concubinos es muy polémico. Cierto es que otras legislaciones, como la panameña, la mejicana y la boliviana, sí conceden a los concubinos derechos similares a los del matrimonio. Sin embargo, en el Perú este sigue siendo un tema de análisis, y quizás, prontamente de decisiones legislativas. 


\section{Bibliografía}

Álvarez Caperochipi, José. Curso de Derecho de Familia. Tomos I y II. Burgos: Editorial Civitas 1988.

Belluscio, Augusto. Derecho de familia. Buenos Aires: Editorial de Palma, 1979.

Borda, Guillermo. Manual de derecho de familia. Buenos Aires: Editorial Perrot, 1988.

Bossert, Gustavo A. Régimen jurídico del concubinato. Buenos Aires: 1990.

Cornejo ChÁvez, Héctor. Derecho familiar peruano. Lima: Gaceta Jurídica Editores, 1998.

Domínguez Águila, Ramón. «Aspectos comparativos del régimen de bienes y de la capacidad de la mujer casada». En Revista de Derecho 163, Universidad de Concepción, Chile.

ECheCopar García, Luis. Régimen legal de bienes en el matrimonio. Lima: 1952.

FARSI, Santiago. «Regímenes matrimoniales». En Revista del Colegio de Abogados de Buenos Aires, vol. 12, Buenos Aires, 1994.

Gómez Piedraita, Hernán. Derecho de familia. Santa Fe de Bogotá: Editorial Temis, 1992.

Lledó Yague, Francisco. Compendio de derecho de familia. Madrid: Editorial Dykinson, 1999.

López del Carril, Julio. Derecho de familia. Buenos Aires: Editorial Abeledo Perrot, 1984.

Martínez VÁsQuez de CASTRO, Luis. Responsabilidad patrimonial de la sociedad de gananciales. Burgos: Editorial Civitas, 1995.

Méndez Costa, María Josefa. Estudios sobre sociedad conyugal. Santa Fe: Rubinzal Culzoni Editores, 1981.

Méndez Costa, María Josefa. Derecho de familia. Santa Fe: Rubinzal Culzoni Editores, 1990.

Rivera FernÁNDEZ, Manuel. La comunidad post ganancial. Barcelona: Editorial Bosch, 1997.

VAZ Ferreira, Eduardo. «Los regímenes matrimoniales en el derecho comparado». En Cuadernos del Centro de Estudios de Derecho Comparado, núm. 3, Facultad de Derecho, Montevideo, 1958.

VIDAL TAQuín, Carlos. El régimen de bienes en el matrimonio. Buenos Aires: Editorial Astrea SRL, 1993.

Zannoni, Eduardo. Derecho de familia. Buenos Aires: Editorial Astrea, 1998. 